\title{
Glial Cells Promote Myelin Formation and Elimination
}

\author{
Alexandria N. Hughes* \\ Section of Developmental Biology, Department of Pediatrics, University of Colorado, Aurora, Aurora, CO, United States
}

Building a functional nervous system requires the coordinated actions of many glial cells. In the vertebrate central nervous system (CNS), oligodendrocytes myelinate neuronal axons to increase conduction velocity and provide trophic support. Myelination can be modified by local signaling at the axon-myelin interface, potentially adapting sheaths to support the metabolic needs and physiology of individual neurons. However, neurons and oligodendrocytes are not wholly responsible for crafting the myelination

OPEN ACCESS

Edited by:

Nathan Anthony Smith

Children's National Hospital,

United States

Reviewed by:

Vittorio Gallo,

Children's National Hospital,

United States

David Lyons,

University of Edinburgh,

United Kingdom

Robert H. Miller,

George Washington University,

United States

*Correspondence:

Alexandria N. Hughes

alexandria.n2.hughes@

cuanschutz.edu

orcid.org/0000-0003-3922-7045

Specialty section:

This article was submitted to

Molecular Medicine,

a section of the journal

Frontiers in Cell and Developmental

Biology

Received: 30 January 2021

Accepted: 07 April 2021

Published: 11 May 2021

Citation:

Hughes AN (2021) Glial Cells

Promote Myelin Formation

and Elimination.

Front. Cell Dev. Biol. 9:661486.

doi: 10.3389/fcell.2021.661486 patterns seen in vivo. Other cell types of the CNS, including microglia and astrocytes, modify myelination. In this review, I cover the contributions of non-neuronal, nonoligodendroglial cells to the formation, maintenance, and pruning of myelin sheaths. I address ways that these cell types interact with the oligodendrocyte lineage throughout development to modify myelination. Additionally, I discuss mechanisms by which these cells may indirectly tune myelination by regulating neuronal activity. Understanding how glial-glial interactions regulate myelination is essential for understanding how the brain functions as a whole and for developing strategies to repair myelin in disease.

Keywords: myelin, oligodendrocyte, glial-glial interactions, astrocyte, microglia

\section{INTRODUCTION}

Communication in the central nervous system (CNS) depends on faithful and timely action potential (AP) propagation along neuronal axons. These demands are in part met by myelin, a proteolipid-rich membrane that insulates axons to increase conduction velocity. Myelin is an evolutionary solution that reconciles the CNS need for speedy conduction with the size limitations of the animal brain: Insulation increases conduction velocity exponentially more effectively than increasing axon diameter, and takes only a fraction of the space. Given this advantage, it is perhaps unsurprising that myelin has evolved at least seven independent times among animals (Hartline and Colman, 2007). Nearly all of these myelin analogs share a similar structure and organization, including multilamellar membrane wraps that extend along axons, punctuated by gaps (nodes of Ranvier). With the exception of copepods, a remarkable feature of myelin membrane is that it is not produced by neurons (Wilson and Hartline, 2011). Instead, myelin is formed by glial cells. In the CNS of vertebrates, the myelinating glia are oligodendrocytes. The non-neuronal origin of a substance integral for neuronal AP propagation is consistent with the possibility that glia are conserved calibrators of neural circuits, optimizing circuit timing and function.

Myelin wraps axons to increase conduction velocity. Something underappreciated about myelination is variability: Oligodendrocytes can form different numbers of myelin sheaths, with different lengths and thicknesses. Consequently, axons display substantial variability in myelin patterning and coverage. Some axons are not myelinated, and among those that are, myelination can be complete or intermittent (Tomassy et al., 2014). Intriguingly, all of these varying parameters, 
including oligodendrocyte differentiation, myelin sheath number, length, and thickness, and axon selection can be promoted by neuronal activity, a subject that has been reviewed extensively (Fields, 2015; Bergles and Richardson, 2016; Hughes and Appel, 2016; Almeida and Lyons, 2017; Mount and Monje, 2017; Thornton and Hughes, 2020). But while neuronal activity can promote myelination, myelin variability persists in experiments in which activity is blocked (Etxeberria et al., 2016) or neurons are replaced with nanofibers (Bechler et al., 2015), indicating that activity is only one of potentially numerous factors that foster the tremendous variability of myelin. What other factors contribute to myelin variability? An emerging body of work indicates that other glial cells, including astrocytes, microglia, and cell types of the vasculature, are also critical myelin cultivators. By promoting oligodendrocyte differentiation, providing materials from which to build myelin, and pruning sheaths, glial cells are intimately involved in nurturing myelin throughout development.

Reductionist approaches have been essential for dissecting the individual roles of glia in the nervous system. These approaches have typically centered on neurons-for example, assaying neuronal physiology upon specific glial manipulationsbecause it is well accepted that altered neuronal function might change CNS function. Here, I evaluate the literature from a different reductionist standpoint. In this review, I center on myelinating oligodendrocytes and explore how other glial cells support the growth and elimination of myelin sheaths. I cover what is known about regulation of myelin sheaths by other glia, including astrocytes, microglia, and cell types of the vasculature. Specifically, I discuss the contributions of these cell types to myelin synthesis and remodeling of myelin. I take the liberty of combining findings that span model systems, CNS regions, and developmental stages and disease states (e.g., remyelination paradigms) with the goal of identifying common functional roles for glia that may transcend specific experimental constraints. Additionally, I discuss how these cell types may regulate neuronal activity to induce activity-dependent plastic changes in myelin. I begin by providing an overview of relevant phases of oligodendrocyte differentiation, myelination, and remodeling, and the following sections on glial interactions with myelin will follow this developmental organization.

\section{OLIGODENDROCYTE DEVELOPMENT AND PLASTICITY}

Oligodendrocytes develop from oligodendrocyte precursor cells (OPCs). During development, OPCs are specified and migrate toward target axons before they differentiate into myelinating cells. In the mammalian forebrain, OPCs are born and migrate from three germinative zones in successive waves (Kessaris et al., 2006), whereas in the spinal cord OPCs are born and migrate in two waves. In both of these regions, the first wave is located ventrally: the medial ganglionic eminence (MGE) in forebrain and the progenitor of motor neuron ( $\mathrm{pMN}$ ) domain of the ventral spinal cord. Later, the ventricular zone of the lateral ganglionic eminence (LGE) and cortex give rise to OPCs, and a dorsal population of spinal cord OPCs are born (Kessaris et al., 2006;
Winkler et al., 2018). From these birth locations, OPCs migrate to evenly distribute in the CNS (Noll and Miller, 1993; Ono et al., 1995; Kirby et al., 2006; Hughes et al., 2013). What cues direct OPCs to migrate long distances to attain their final positions in the CNS (Figure 1)? Axon- and meningeal-derived cues, including Tgf $\beta$-1 (Choe et al., 2014) and Eph/Ephrin signaling (Prestoz et al., 2004), are one source of cues. Another, more local interaction occurs when OPCs interact with the vasculature. In our section on Vasculature, I examine the role of OPCvasculature interactions in directed migration.

Following migration, OPCs begin to differentiate. Premyelinating oligodendrocytes elaborate processes that wrap axons and begin to synthesize myelin proteins and lipids that comprise the myelin sheath. Whether OPCs that do not differentiate represent an equipotent reserve pool or are a distinct subset with yet unknown functions is not entirely clear. OPC numbers are maintained by homeostatic proliferation and differentiation (Kirby et al., 2006; Hughes et al., 2013) and in the absence of axonal targets OPC proliferation and survival are moderately reduced, indicating that the population is responsive and matched to target availability (Almeida and Lyons, 2016). However, recent work indicates that multiple OPC subtypes exist and are separable by transcriptomics, intracellular calcium signaling, and membrane ion channels and receptors (Marques et al., 2016; Spitzer et al., 2019; Marisca et al., 2020), raising the possibility that both a differentiation reserve pool and other functional pools exist. For the purposes of this review, I will focus on those cells that do eventually myelinate and point the reader toward reviews covering OPCs in more detail (Mangin and Gallo, 2011; Bergles and Richardson, 2016). What controls the onset of differentiation? Several regulatory factors have been identified (Elbaz and Popko, 2019), and OPCs appear to divide a specific number of times prior to differentiation, consistent with an intrinsic timer mechanism (Temple and Raff, 1986; Raff, 2007). However, extracellular cues are also critical for differentiation (Wheeler and Fuss, 2016). For example, the OPC intrinsic timer depends on PDGF from astrocytes (Raff et al., 1988). Do other glial-derived factors support differentiation? Astrocytes, microglia, and endothelial cells, typically absent from culture, secrete cues that promote differentiation and can guide processes toward axons.

A major manifestation of differentiation is the production of myelin. Myelin is a specialized membrane that differs from the plasma membrane, particularly enriched in lipids, comprising $75 \%$ of the dry weight of myelin (Nave and Werner, 2014), and proteins that organize myelin structure and adhesion to the axon. Perhaps because there are fewer methods available to study lipids compared to proteins (Muro et al., 2014), lipid localization and trafficking in myelin is somewhat a technical blind spot in myelin biology. Instead, investigations have studied the genes and proteins that regulate lipid synthesis, with the caveat that synthesized lipids may localize differently than the enzymes that synthesize them. This approach revealed that cholesterol is required for the earliest stages of axon wrapping: wrapping is almost entirely blocked by global loss of function mutation of hmgcs 1, which encodes the rate-limiting enzyme for cholesterol synthesis (Mathews et al., 2014). Do oligodendrocytes 

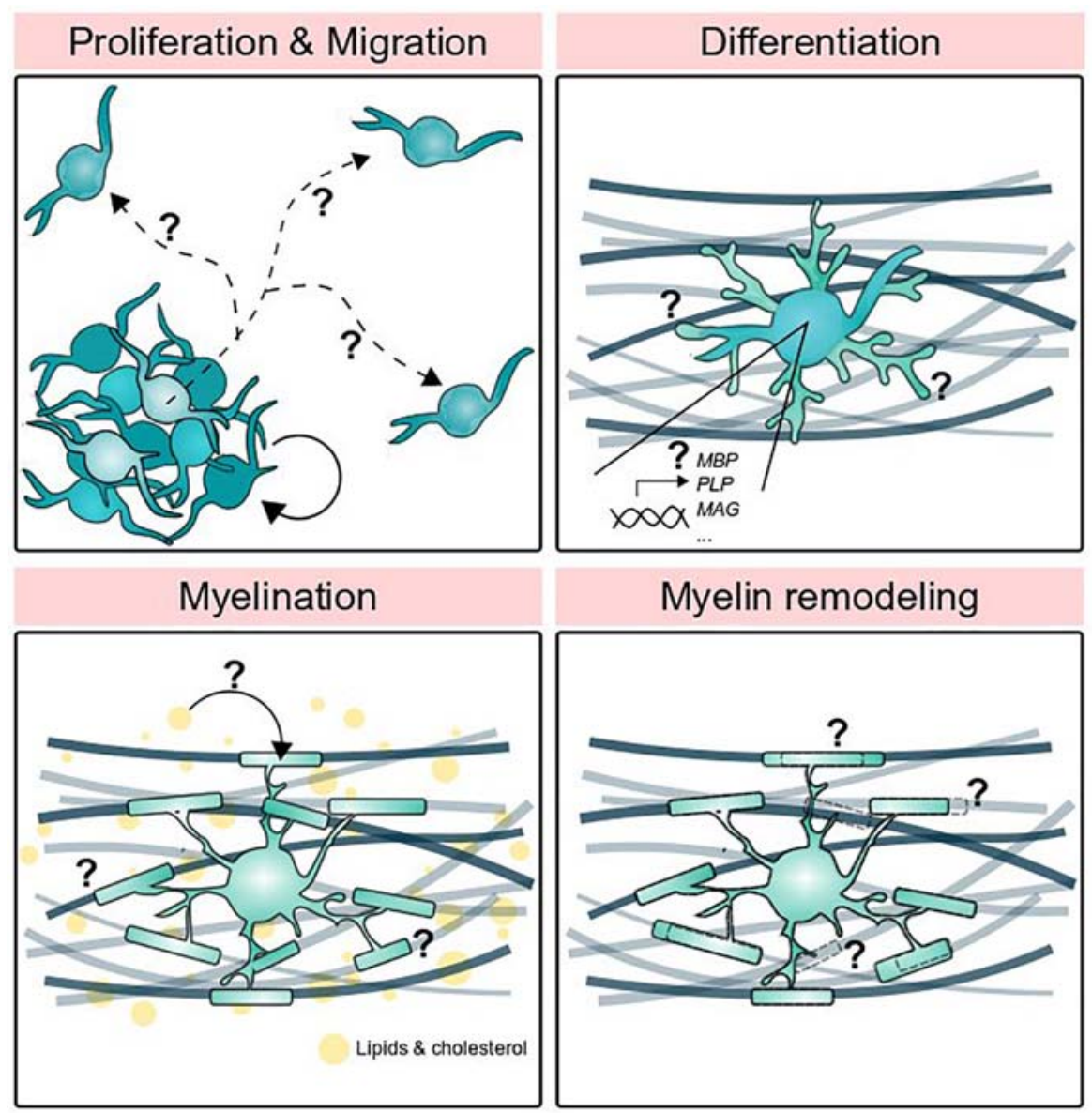

FIGURE 1 | Stages of oligodendrocyte development supported by other glial cells. Oligodendrocyte precursor cells proliferate and migrate, but what determines precise migratory routes and proliferation rate? How do oligodendrocytes differentiate and turn on myelin gene expression? Circulating lipids are a major component of myelin, but where do those lipids come from? Finally, how do myelin sheaths grow, shrink, and disappear altogether?

synthesize cholesterol and other lipids autonomously? Mice with oligodendrocyte-specific deletion of fatty acid synthase (Fasn) had hypomyelination in various CNS regions, but this could be partially rescued by increasing dietary lipids (Dimas et al., 2019). Additionally, in mice with oligodendrocyte-specific deletion of Fdft1, the gene encoding squalene synthase necessary for cholesterol synthesis, myelin still contained cholesterol, consistent with the possibility that oligodendrocytes obtain cholesterol from another source (Saher et al., 2005). Indeed, lipid analysis of purified myelin has revealed that oligodendrocytes incorporate circulating lipids to build myelin (Nave and Werner, 2014; Camargo et al., 2017), consistent with the possibility that proximal neurons and glia also provide and influence the lipids available for myelin construction.

The advancement of myelin around the axon and successful subversion of previous layers requires coordinated adhesion, both between layers of myelin as well as adhesion between the myelin and axon. The proteins myelin basic protein (MBP) and proteolipid protein (PLP), which together account for $68 \%$ of total myelin protein (Jahn et al., 2020) regulate myelin sheath compaction by adhering internal and external membrane leaflets, respectively. MBP is also required for actin disassembly during wrapping to promote membrane spreading (Zuchero et al., 2015). To promote adhesion to the axon, adhesion proteins must be corralled into the lateral edges that will form the paranodal loops that adhere to the axon (Rasband and Peles, 2016). The most well-studied adhesion protein at the paranodal interface is neurofascin-155 (NF155), a glial protein that binds axonal contactin-1 (Cntn1) and contactinassociated protein (Caspr) (Gollan et al., 2003). Additional adhesion molecules from the immunoglobulin superfamily, including Tag-1, Cadm1, and Cadm4, also coordinate axonmyelin adhesion along the juxtaparanode and internode (Poliak et al., 2003; Traka et al., 2003; Elazar et al., 2018; Hughes and Appel, 2019). Manipulation of these adhesion molecules disrupts myelin sheath number, length, targeting to axons, and lamellar organization (Djannatian et al., 2019; Elazar et al., 2019; Garcia and Zuchero, 2019; Hughes and Appel, 2019; Klingseisen et al., 2019). Modification of adhesion complexes, either autonomously by the axon or myelin, or potentially by other glial cells, represents one way that myelination can be changed. 
After initial axon wrapping, myelination is not finalized is continuously subject to turnover and updates throughout life. Carbon dating experiments suggest that human myelin and oligodendrocytes are generated and integrated over the lifespan (Yeung et al., 2014). Further changes in myelin can be spurred by experience. Learning how to juggle and play the piano, activities that engage select populations of neurons, are associated with white matter additions in relevant brain areas (Scholz et al., 2009). This activity-dependent myelin growth, or "myelin plasticity," includes adaptation of existing myelin and addition of new myelin sheaths by existing cells (Duncan et al., 2018; Bacmeister et al., 2020; Yang et al., 2021) as well as proliferation and subsequent differentiation of new oligodendrocytes (Barres and Raff, 1993; Gibson et al., 2014). At the cellular level, optogenetic or chemogenetic stimulation of neurons (Gibson et al., 2014; Mitew et al., 2018) or expression of neurotoxins to silence neurons (Hines et al., 2015; Mensch et al., 2015; Wake et al., 2015; Koudelka et al., 2016) demonstrate that myelin adapts to neuronal activity. Another side of myelin plasticity is myelin elimination. Although mechanisms of elimination are incompletely resolved, elimination is often referred to as "retraction" (Fields, 2015; Hines et al., 2015; Mensch et al., 2015; Baraban et al., 2018; Krasnow et al., 2018; Bacmeister et al., 2020), “contraction" (Yang et al., 2021), or "pruning" (Liu et al., 2013). Do activity-dependent additions or loss of myelin impact CNS function? Recent findings are consistent with this possibility. New oligodendrocytes and new myelin are required for motor learning and memory preservation (McKenzie et al., 2014; Pan et al., 2020; Steadman et al., 2020; Wang et al., 2020). These systems-level adaptations are presumably driven by activitydependent oligodendrocyte differentiation and myelin growth and remodeling on behaviorally relevant neurons. However, all glial cell types are responsive to neuronal activity (Barres and Raff, 1993; Demerens et al., 1996; Poskanzer and Yuste, 2011; Li et al., 2012; Nagy et al., 2017; Liu et al., 2019; Stowell et al., 2019; Zuend et al., 2020; Nagai et al., 2021), raising the possibility that other glial cells may promote or solidify adaptive changes by regulating properties of myelin. Getting the whole picture will require learning not only how cell types interact with one another in isolation, but also how these interactions moderate each other in the context of the whole brain.

\section{ASTROCYTE INTERACTIONS WITH THE OLIGODENDROCYTE LINEAGE AND MYELIN}

Astrocytes develop before oligodendrocytes, both in vivo and in culture (Qian et al., 2000), consistent with the possibility that astrocytes influence the entire course of oligodendrocyte development. Astrocytes secrete PDGF and FGF, which promote the proliferation and impede the differentiation of OPCs (Barnett and Linington, 2013; Lundgaard et al., 2014; Figure 2). The relationship between OPCs and astrocytes during OPC differentiation is less well resolved. Several lines of evidence raise the possibility that astrocytes help control the timing of myelination. One mechanism that occurs during OPC differentiation is the translocation of hundreds of mRNAs into premyelinating processes, presumably to enable local translation of proteins relevant for sheath maturation (Thakurela et al., 2016). The archetypal mRNA studied in this process is $M b p$ mRNA, which translocates into myelinating processes both in culture and in vivo (Ainger et al., 1993; Herbert et al., 2017; Yergert et al., 2021). MBP is classically known for driving myelin compaction (Readhead et al., 1987) and has recently been implicated in actin disassembly during myelin wrapping (Zuchero et al., 2015), raising the possibility that locally translated $\mathrm{MBP}$ is integral to wrapping. In vitro labeling of $M b p$ mRNA in oligodendrocyte-astrocyte cocultures revealed that direct contact with astrocytes inhibited mRNA translocation into oligodendrocyte processes (Amur-Umarjee et al., 1993), but the presence of neurons alleviated this inhibition via PDGF-AB and -BB secretion (Amur-Umarjee et al., 1997). This is consistent with a role for astrocytic contact in limiting myelinating potential of processes when neurons are unavailable as substrates for myelination. Complementing this interpretation, co-cultured astrocytes guided oligodendrocyte processes to align with retinal ganglion cell axons (Meyer-Franke et al., 1999), increased the fraction of axons selected for myelination (Sorensen et al., 2008), and enhanced myelin growth and thickness (Watkins et al., 2008). Taken together, these studies raise the intriguing possibility that astrocytic contact may regulate the timing of myelination, ensuring that oligodendrocyte processes are aligned with axons before permitting mRNA translocation and presumably local synthesis of myelin proteins. Such a timing mechanism is also supported by astrocytic secretion of factors that both promote and inhibit myelin wrapping (Table 1 and Figure 3).

At myelination onset, astrocytes play a critical role in producing lipids for myelin synthesis. Recent evidence showed that astrocytes provide the majority of required lipids to oligodendrocytes (Camargo et al., 2017). Astrocyte-specific deletion of the major lipid biosynthesis regulator SREBP cleavage activating protein (SCAP) caused more severe and persistent hypomyelination than oligodendrocyte-specific loss of SCAP, which resolved after a brief developmental delay (Camargo et al., 2017). This is consistent with previous findings from a mouse model of oligodendrocyte-specific deletion of Fdft1, the gene encoding squalene synthase, also required for cholesterol synthesis, which exhibited early hypomyelination that also caught up by adulthood (Saher et al., 2005). Therefore, in addition to uptake of lipids and cholesterol from the extracellular environment (Saher et al., 2005; Nave and Werner, 2014; Camargo et al., 2017), oligodendrocytes build myelin primarily from astrocyte-derived lipids. The transfer mechanism is incompletely resolved and could involve direct transfer or uptake of astrocyte-derived lipids and cholesterol from the extracellular milieu. Intriguingly, lipid availability may vary with regional astrocyte heterogeneity. Gray matter astrocytes may secrete more cholesterol than white matter astrocytes, and inhibiting cholesterol synthesis from white matter-derived astrocytes improved in vitro myelination (Werkman et al., 2020), raising the possibility that different populations of astrocytes provide different support for nearby oligodendrocytes. Together, these data extend the known role of astrocytes in 


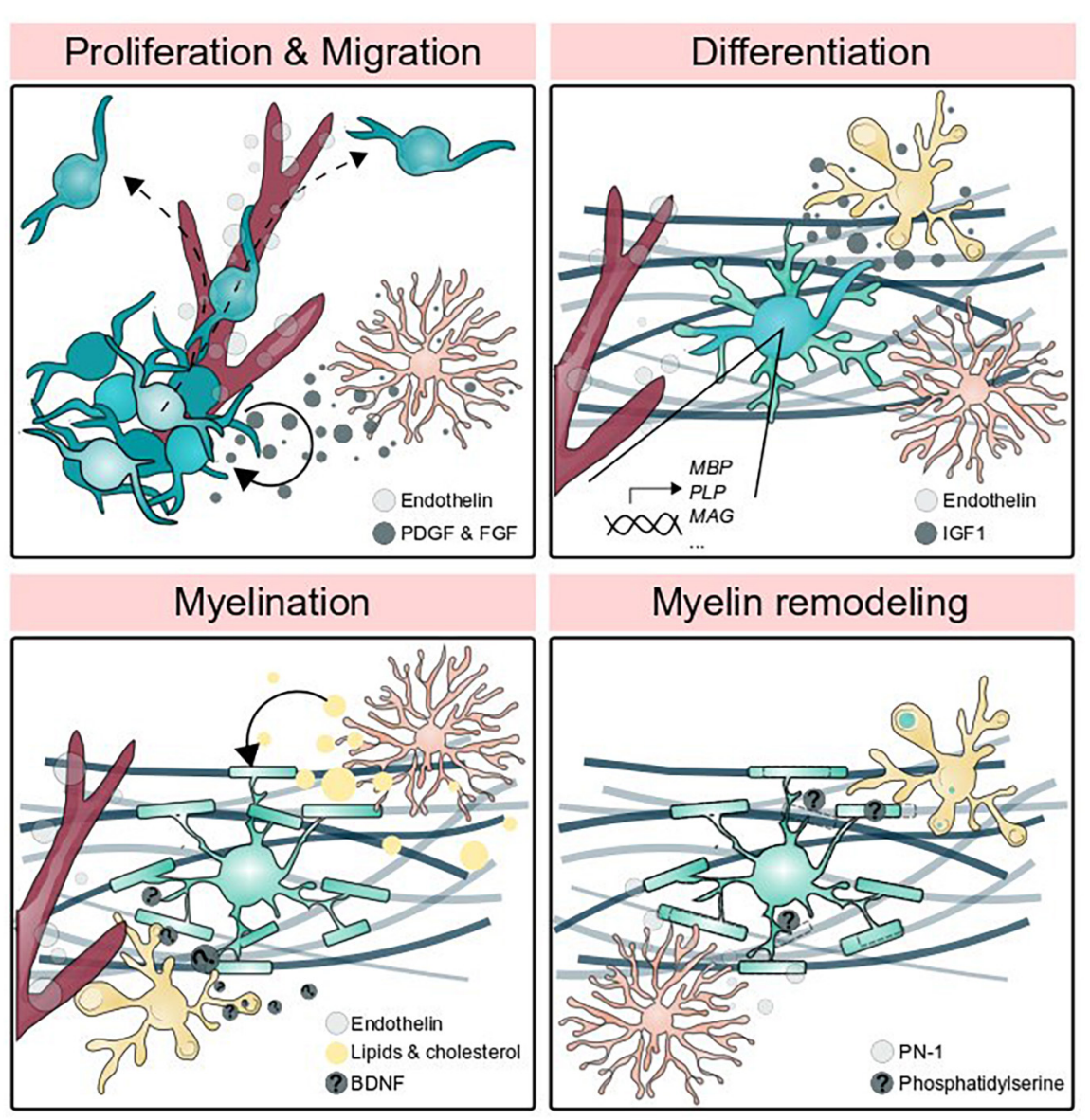

FIGURE 2 | Glial cells promote myelin formation and elimination. Oligodendrocyte precursor cell proliferation is promoted by astrocytic PDGF and FGF signaling and OPCs migrate along the vasculature. Endothelin secreted by endothelial cells and IGF1 secreted by microglia promote differentiation, and astrocytes guide OPCs to axons. The generation of myelin membrane (which may be thought of as one feature of differentiation) utilizes lipids and cholesterol produced by astrocytes, BDNF secreted by neurons and potentially augmented by microglia-secreted BDNF, and endothelin signaling to the receptor EDNRB located on oligodendrocytes. Astrocytic secretion of $\mathrm{PN}-1$ promotes myelin stability by inhibiting thrombin-mediated paranodal lifting, whereas microglia phagocytose myelin by detecting phosphatidylserine.

providing cholesterol to neurons to promote synapse formation (Mauch et al., 2001) to include oligodendrocytes to enable myelin formation.

Oligodendrocytes and astrocytes maintain contact through somatic and lamellar gap junctions, which might promote myelination and serve to ensure ionic balance. These heterotypic gap junctions can be formed by astrocytic expression of $\mathrm{Cx} 30$ or $\mathrm{Cx} 43$ and oligodendroglial expression of $\mathrm{Cx} 32$ or Cx47 (Nagy et al., 2003; Orthmann-Murphy et al., 2007b). Deletion of different subsets of these connexins has provided evidence that converges on a role for gap junctions in myelin formation or maintenance: loss of $\mathrm{Cx} 30$ and $\mathrm{Cx} 43$ was associated with myelin vacuolization (Lutz et al., 2009), recessive mutations in the gene encoding $\mathrm{Cx} 47$ cause PelizaeusMerzbacher-like disease, a dysmyelinating disease in humans (Orthmann-Murphy et al., 2007a,b), and loss of Cx32 was associated with cortical myelin defects and hyperexcitability (Sutor et al., 2000). Mechanistically, a precise role for O-A coupling in myelination has been elusive. Deletion of the genes encoding $\mathrm{Cx} 32$ and $\mathrm{Cx} 47$ in oligodendrocytes was associated with dysregulation of lipid synthesis genes and an immune response (Wasseff and Scherer, 2015) and loss of Cx30 and $\mathrm{Cx} 43$ reduced levels of Mbp in corpus callosum (Lutz et al., 2009), raising the possibility that O-A coupling supports myelin gene expression. A potential confound to this interpretation is that loss of coupling may leave oligodendrocytes susceptible to excitotoxic damage, and myelin reductions observed in these models might reflect injury rather than impaired development. Indeed, O-A junctions allow $\mathrm{K}^{+}$influx in oligodendrocytes and astrocytes to diffuse into the syncytium, protecting coupled cells from high concentrations of $\mathrm{K}^{+}$and excitotoxic damage (Nagy and Rash, 2000; Menichella et al., 2006; Battefeld et al., 2016). Distinguishing the relative contributions of gap junction coupling to promoting myelination and protecting cells from excitotoxic damage has the potential to teach us a lot about oligodendrocyte development and heterogeneity, especially given the vast regional variation in O-A coupling frequency (Wasseff and Scherer, 2011). 
TABLE 1 | Glial secreted factors that shape oligodendrocyte development.

\begin{tabular}{|c|c|c|c|c|}
\hline Factor & $\begin{array}{l}\text { Glial cell types that } \\
\text { produce factor }\end{array}$ & $\begin{array}{l}\text { Oligodendrocyte } \\
\text { developmental stage }\end{array}$ & Effect & References \\
\hline $\begin{array}{l}\text { Platelet-derived growth } \\
\text { factor (PDGF) }\end{array}$ & Astrocytes & Proliferation & Promotes & $\begin{array}{l}\text { Noble et al., 1988; Raff et al., 1988; } \\
\text { Richardson et al., 1988; Hart et al., } \\
\text { 1989; Barnett and Linington, 2013; } \\
\text { Lundgaard et al., } 2014\end{array}$ \\
\hline $\begin{array}{l}\text { Fibroblast growth } \\
\text { factor-2 (FGF2) }\end{array}$ & $\begin{array}{l}\text { Astrocytes, microglia, } \\
\text { OPCs }\end{array}$ & Proliferation & Promotes & $\begin{array}{l}\text { Liu et al., 1998; Messersmith et al., } \\
\text { 2000; Fortin et al., 2005; Barnett and } \\
\text { Linington, 2013; Kirby et al., 2013; } \\
\text { Birey et al., } 2015\end{array}$ \\
\hline $\begin{array}{l}\text { Transglutaminase-2 } \\
\text { (Tgm2) }\end{array}$ & Microglia, astrocytes & Proliferation & Promotes & $\begin{array}{l}\text { Giera et al., 2018; Espitia Pinzon et al., } \\
2019\end{array}$ \\
\hline Interleukin 6 (IL-6) & Microglia, astrocytes & Proliferation & Promotes & $\begin{array}{l}\text { Barres et al., 1993; Lau and Yu, 2001; } \\
\text { Taylor et al., 2010; Shigemoto-Mogami } \\
\text { et al., } 2014\end{array}$ \\
\hline Interleukin $1 \beta(\mathrm{IL}-1 \beta)$ & Microglia, astrocytes & Proliferation & Promotes & $\begin{array}{l}\text { Didier et al., 2004; Shigemoto-Mogami } \\
\text { et al., } 2014\end{array}$ \\
\hline $\begin{array}{l}\text { Ciliary neurotrophic } \\
\text { factor (CNTF) }\end{array}$ & Astrocytes & $\begin{array}{l}\text { Survival, proliferation, } \\
\text { differentiation (?) }\end{array}$ & $\begin{array}{l}\text { Reports of both pro- and } \\
\text { absent effect on differentiation }\end{array}$ & $\begin{array}{l}\text { Barres and Raff, 1993; Barres et al., } \\
\text { 1996; Stankoff et al., 2002; Albrecht } \\
\text { et al., 2003; Nash et al., } 2011\end{array}$ \\
\hline Pleiotrophin (Ptn) & Astrocytes, pericytes & $\begin{array}{l}\text { Proliferation, } \\
\text { differentiation }\end{array}$ & $\begin{array}{l}\text { Promotes proliferation, } \\
\text { suppresses differentiation }\end{array}$ & $\begin{array}{l}\text { Yeh et al., 1998; Kuboyama et al., } \\
\text { 2012, 2015, 2016; Mcclain et al., } \\
\text { 2012; Nikolakopoulou et al., } 2019\end{array}$ \\
\hline $\begin{array}{l}\text { Insulin-like growth } \\
\text { factor-1 (IGF1) }\end{array}$ & Microglia, astrocytes & $\begin{array}{l}\text { Proliferation, } \\
\text { differentiation }\end{array}$ & Promotes & $\begin{array}{l}\text { Ye et al., 2002; Shigemoto-Mogami } \\
\text { et al., 2014; Pitt et al., 2017; } \\
\text { Wlodarczyk et al., 2017; Chen et al., } \\
2019\end{array}$ \\
\hline $\begin{array}{l}\text { Tumor necrosis } \\
\text { factor- } \alpha(\mathrm{TNF} \alpha)\end{array}$ & Microglia, astrocytes & $\begin{array}{l}\text { Proliferation (?), } \\
\text { differentiation }\end{array}$ & $\begin{array}{l}\text { Reports of both pro- and } \\
\text { anti-proliferative effects }\end{array}$ & $\begin{array}{l}\text { Arnett et al., 2001; Lau and Yu, 2001; } \\
\text { Nakazawa et al., 2006; Taylor et al., } \\
\text { 2010; Su et al., 2011; } \\
\text { Shigemoto-Mogami et al., } 2014\end{array}$ \\
\hline Interferon $\gamma(\mathrm{IFN}-\gamma)$ & Microglia, astrocytes & Differentiation & $\begin{array}{l}\text { Inhibits differentiation, induces } \\
\text { cell stress and death }\end{array}$ & $\begin{array}{l}\text { Baerwald and Popko, 1998; Laferla } \\
\text { et al., 2000; Lau and Yu, 2001; Chew } \\
\text { et al., 2005; Lin et al., 2006; } \\
\text { Shigemoto-Mogami et al., } 2014\end{array}$ \\
\hline Endothelin 1 (ET-1) & $\begin{array}{l}\text { Endothelial cells, radial glia, } \\
\text { astrocytes }\end{array}$ & Differentiation & Promotes & $\begin{array}{l}\text { Ostrow et al., 2011; Swire et al., 2019; } \\
\text { Adams et al., } 2020\end{array}$ \\
\hline Laminin, a2 (LAMA2) & Pericytes, astrocytes? & Differentiation & Promotes & $\begin{array}{l}\text { De La Fuente et al., 2017; Silva et al., } \\
2019\end{array}$ \\
\hline $\begin{array}{l}\text { Chondroitin sulfate } \\
\text { proteoglycan } 4 \\
\text { (CSPG4, NG2) }\end{array}$ & OPCs, pericytes, microglia & Differentiation & $\begin{array}{l}\text { Favors differentiation of } \\
\text { astrocytes at expense of } \\
\text { oligodendrocytes }\end{array}$ & $\begin{array}{l}\text { Baror et al., 2019; Huang et al., 2020; } \\
\text { Liu et al., } 2021\end{array}$ \\
\hline Lipids and Cholesterol & Astrocytes, microglia & Myelination & $\begin{array}{l}\text { Promotes; microglia sterols } \\
\text { support remyelination }\end{array}$ & $\begin{array}{l}\text { Saher et al., 2005; Mathews et al., } \\
\text { 2014; Camargo et al., 2017; Dimas } \\
\text { et al., 2019; Werkman et al., 2020; } \\
\text { Berghoff et al., } 2021\end{array}$ \\
\hline $\begin{array}{l}\text { Brain-derived } \\
\text { neurotrophic factor } \\
\text { (BDNF) }\end{array}$ & Astrocytes, microglia & Myelination & Promotes & $\begin{array}{l}\text { Nakajima et al., 2002; Coull et al., } \\
\text { 2005; Gomes et al., 2013; Parkhurst } \\
\text { et al., 2013; Fulmer et al., } 2014\end{array}$ \\
\hline $\begin{array}{l}\text { Leukemia inhibitory } \\
\text { factor (LIF) }\end{array}$ & Astrocytes & Myelination & Promotes & $\begin{array}{l}\text { Barres et al., 1993; Butzkueven et al., } \\
\text { 2002; Ishibashi et al., 2006; Moidunny } \\
\text { et al., } 2012\end{array}$ \\
\hline $\begin{array}{l}\text { C-X-C motif chemokine } \\
\text { ligand } 10(\mathrm{CXCL} 10)\end{array}$ & Astrocytes & Myelination & Inhibits axon wrapping & Nash et al., 2011 \\
\hline Phosphatidylserine (PS) & Oligodendrocytes & Myelin remodeling & Eat-me signal for microglia & Djannatian et al., 2021 \\
\hline $\begin{array}{l}\text { Protease nexin-1 } \\
\text { (PN-1, SERPINE2) }\end{array}$ & Astrocytes & Myelin remodeling & Inhibits myelin lifting & Dutta et al., 2018 \\
\hline
\end{tabular}

Astrocytes are also emerging as regulators of myelin remodeling. Over $95 \%$ of nodes of Ranvier are contacted by astrocytes (Serwanski et al., 2017), a position that grants astrocytes proximity to many neighboring myelin sheaths. Exocytosis of a thrombin inhibitor, protease nexin-1 (PN-1, encoded by Serpine2) from astrocytes prevented thrombinmediated cleavage of NF155 (Dutta et al., 2018), which anchors myelin paranodal loops to the axon. Thrombin is expressed by neurons and can also enter the CNS from the vasculature. At steady state, some NF155 was cleaved, evidenced by myelin lifting 


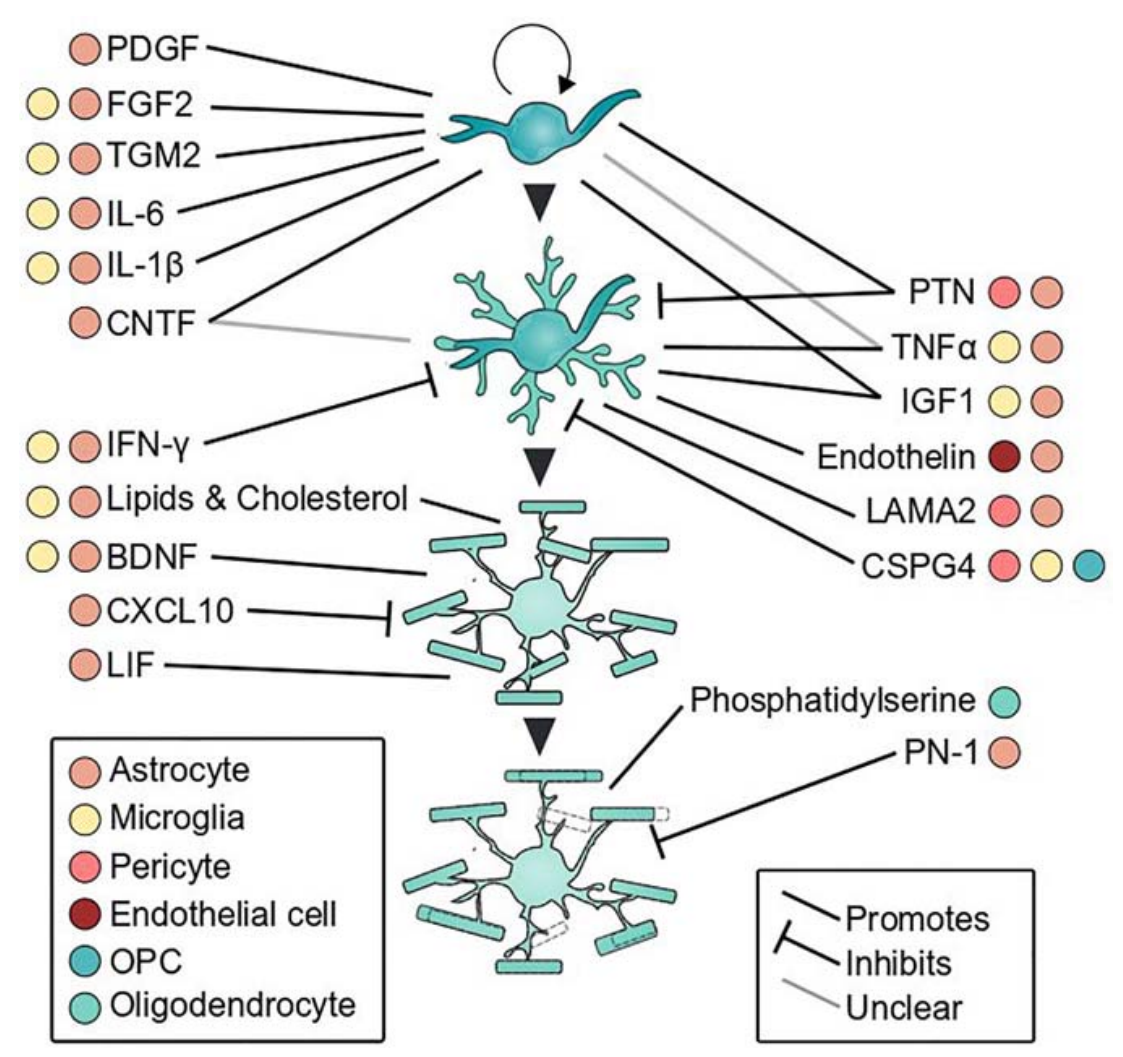

FIGURE 3 | Glial secreted factors that influence oligodendrocyte development. Oligodendrocyte proliferation, differentiation, myelination, and myelin remodeling are shaped by cues secreted by glial cells. Colored dots indicate cell types that secrete each factor and line type denotes direction of effect. References for each factor are listed in Table $\mathbf{1 .}$

at $20 \%$ of observed paranodes. Blocking astrocytic exocytosis to prevent $\mathrm{PN}-1$ secretion further increased the number of detached paranodes, consistent with the possibility that PN1 promotes sheath stability by preventing thrombin-mediated NF155 cleavage. Under the model proposed by the authors, thrombin can increase paranodal lifting to allow for resorption of the outermost layer of myelin by the oligodendrocyte cell body. The resorption of myelin should be distinguished from other ways that astrocytes have been shown to remodel myelin, such as via phagocytosis. Astrocyte-like radial glia phagocytose optic nerve myelin in frogs (Mills et al., 2015), raising the possibility that both paranodal lifting and sheath phagocytosis contribute to sheath remodeling. Further investigation of these mechanisms in vivo might better resolve the conditions that contribute to different mechanisms of remodeling, potentially including regional astrocyte availability and heterogeneity (Bayraktar et al., 2015).

\section{MICROGLIAL INTERACTIONS WITH OLIGODENDROCYTE LINEAGE CELLS AND MYELIN}

Microglia are resident immune cells of the CNS that differentiate from macrophages. Tools that allow manipulation of macrophages and microglia have been invaluable for uncovering how microglia contribute to oligodendrocyte development and myelination. Microglia development is covered in more depth elsewhere (Nayak et al., 2014), but here I introduce features that are relevant to manipulation. Erythromyeloid progenitors in the yolk sac are specified to become either macrophages or neutrophils in an interferon regulatory factor 8 (IRF8) -dependent manner (Holtschke et al., 1996; Scheller et al., 1999; Shiau et al., 2015). A subset of yolk sac macrophages will then invade the CNS and differentiate into microglia. The distribution and survival of microglia within the CNS depends on the function of the receptor CSF1R, which binds ligands IL-34 and CSF-1 (Ginhoux et al., 2010; Erblich et al., 2011; Oosterhof et al., 2018). Whereas both IRF8 and CSF1R disruption have allowed investigators to study how the CNS develops without microglia, CSF1R inhibition is increasingly popular due to the development of inhibitors for this receptor (Elmore et al., 2014). However, CSF1R manipulation also affects peripheral macrophages (Lei et al., 2020; Green and Hume, 2021), and the search for more specific tools has continued. By deleting a super-enhancer in the CSF1R locus, Rojo et al. (2019) generated a new mouse model that lacks brain microglia and a few other populations of macrophages but $\mathrm{CSF}_{\mathrm{N}}{ }^{\triangle \mathrm{FIRE} / \triangle \mathrm{FIRE}}$ mice are healthy and fertile. Additionally, a transmembrane protein, TMEM119, is expressed in microglia but not macrophages 
(Bennett et al., 2016; Satoh et al., 2016) and recently TMEM119 mouse lines have been generated to label and manipulate microglia (Kaiser and Feng, 2019). However, TMEM119 is not expressed by microglia in all model organisms and is notably absent from zebrafish and chicken microglia (Geirsdottir et al., 2019), its expression decreases in inflammatory conditions (Bennett et al., 2016), and it is expressed by a subset of peripheral macrophages during development (Grassivaro et al., 2020). P2RY12 is another promising marker that appears restricted to microglia and dural and choroid plexus macrophages, but not other macrophages (McKinsey et al., 2020). Although all of these existing methods of targeting microglia have limitations, it was recently revealed that microglia-fated macrophages are transcriptionally distinguishable within the yolk sac (Utz et al., 2020). Newly identified markers for yolk sac microglia-fated macrophages may enable the discovery of new targets for earlier and more specific perturbation of the lineage (Utz et al., 2020).

Microglia secrete cues that promote OPC proliferation, differentiation, and myelination. By ablating microglia during early postnatal development (P2-P7) with the CSF1R inhibitor BLZ945, Hagemeyer et al. (2017) found that microglia maintain OPC numbers and myelination in corpus callosum and cerebellum (Hagemeyer et al., 2017). Mice without microglia had fewer OPCs during development and by early adulthood had reduced myelin. Some of the phenotypes varied between brain regions, which could reflect regional heterogeneity in oligodendrocytes (Marques et al., 2016) or microglia (De Biase et al., 2017; Hammond et al., 2019; Li et al., 2019). Indeed, a specific subset of microglia that express $C d 11 c$ are present in developing white matter and ablation or conditional knockout of Igf1 in these cells also impaired myelination (Wlodarczyk et al., 2017). Together, these data suggest that a subset of microglia promote myelination through IGF1 production. Other signaling pathways between microglia and OPCs may also modify myelin development. Giera et al. (2018) found that an adhesion G-protein coupled receptor, GPR56, located on OPCs, interacts with Transglutaminase-2 (TGM2) secreted by microglia to promote OPC proliferation in the presence of the extracellular matrix (ECM) protein laminin-111 (Giera et al., 2018). Importantly, remyelination following a demyelinating lesion was impaired in knockout mice lacking TGM2-GPR56 signaling, suggesting that this microglia-OPC-ECM signaling axis is essential not only for OPC numbers but functional remyelination (Giera et al., 2018). Astrocytes also express TGM2, raising the possibility that regions with differential densities of astrocytes and microglia maintain signaling via this signaling axis (Espitia Pinzon et al., 2019). Furthermore, microglial deposition of the ECM molecule CSPG4 in aging shifts the microenvironment to favor the differentiation of NG2 cells into astrocytes at the expense of oligodendrocytes (Baror et al., 2019). Taken together, microglia-ECM interactions may promote OPC proliferation and differentiation in development but increasingly inhibit OPC differentiation in later life.

In addition to IGF1 production, microglia are secretory cells that generate a variety of molecules and cytokines that have been studied in regulation of neuronal and synaptic activity (York et al., 2018). However, some of these secreted molecules have been independently implicated in regulating myelination. For example, microglia secrete BDNF (Nakajima et al., 2002; Coull et al., 2005; Gomes et al., 2013; Parkhurst et al., 2013), which has been found to promote myelination in numerous contexts (Mctigue et al., 1998; Lundgaard et al., 2013; Geraghty et al., 2019). The contribution of microgliaderived BDNF to myelination has not been investigated, but astrocyte-derived BDNF supports remyelination after cuprizonemediated demyelination (Fulmer et al., 2014), consistent with the possibility that microglial-derived BDNF also promotes myelination. Microglia also secrete factors including TNF $\alpha$, IL6 , FGF2, IL-1 $\beta$, and IFN- $\gamma$ that stimulate OPC proliferation and differentiation (Shigemoto-Mogami et al., 2014; Miron, 2017), but precise roles for these secreted cues in myelination have yet to be investigated.

Recent investigations of microglial heterogeneity have identified a population of white matter-associated microglia present during early postnatal development in mouse (Hammond et al., 2019; Li et al., 2019; McNamara and Miron, 2020). The role of this microglia subset is not yet known, but microglia in this subset $(\mathrm{Clec} 7 a+)$ contain $M b p$ transcripts (Li et al., 2019), raising the possibility that white matter microglia phagocytose myelin or oligodendrocytes. Microglia phagocytose myelin in disease models and in culture (Trotter et al., 1986; van der Laan et al., 1996; Smith and Hoerner, 2000), but a role for myelin engulfment during normal development is only beginning to be understood. We recently used zebrafish to investigate myelin phagocytosis by microglia during development (Hughes and Appel, 2020). We found that microglia dynamically engage with sheaths in myelinated tracts and phagocytose a subset of nascent sheaths. This may imply selective expression of a cue. Intriguingly, a recent preprint identified phosphatidylserine (PS), a known eat-me cue at synapses (Li et al., 2020; Park et al., 2020; Scott-Hewitt et al., 2020), as a likely cue for developmental myelin phagocytosis (Djannatian et al., 2021). Similar to synapse elimination, the cues that direct myelin phagocytosis may vary between brain regions (Gunner et al., 2019). Furthermore, emerging nonphagocytic microglial mechanisms of synapse modification, such as local extracellular matrix modification, may also impact myelin growth and loss (Cheadle et al., 2020; Nguyen et al., 2020). Identifying the cues that regulate myelin phagocytosis and non-phagocytic elimination, and the possibility that those cues may overlap or be distinct from cues regulating synapse elimination has the possibility to teach us a great deal about general principles of brain wiring during development.

\section{VASCULAR INTERACTIONS WITH THE OLIGODENDROCYTE LINEAGE AND MYELIN}

In addition to astrocytes and microglia, cell types of the vasculature also interact with myelinating oligodendrocytes. The vasculature comprises two interacting cell types, endothelial cells and pericytes. During development, OPCs use the vasculature as a physical substrate for migration (Tsai et al., 2016) and 
crawl along it to distribute throughout the CNS. To learn which vascular cell type interacts with OPCs to promote migration, Tsai et al. (2016) used genetic approaches to ablate both endothelial cells and pericytes (Gpr124-/-), or pericytes only $\left(P d g f r b^{-/-}\right)$and studied OPC migration. They found that endothelial cells, and specifically endothelial expression of the adhesion G-protein coupled receptor, GPR124, were required for OPCs to migrate and distribute throughout the CNS. Within OPCs, CXCR4 and autocrine signaling of the Wnt ligands Wnt7a and $-7 \mathrm{~b}$ first promoted attraction to the vasculature, and were downregulated later, presumably allowing for detachment and differentiation (Yuen et al., 2014; Tsai et al., 2016).

Other factors produced by vascular cells may actively promote OPC differentiation and myelination. Endothelial cells produce endothelin, which was shown to promote oligodendrocyte differentiation in the subventricular zone (SVZ) (Adams et al., 2020). In a demyelination paradigm, pericyte secretion of the extracellular matrix protein LAMA2 could stimulate OPC differentiation (De La Fuente et al., 2017), raising the possibility that pericytes also promote differentiation during development via matrix deposition. Taken together, these data suggest a model by which OPCs migrating along vasculature both downregulate CXCR4 and Wnt ligands and are exposed to endothelin and possibly ECM factors to promote differentiation and myelination. In support of this model, Swire et al. (2019) found that upon oligodendrocyte-specific knockout of EDNRB, the endothelin receptor, oligodendrocytes formed fewer myelin sheaths (Swire et al., 2019). These authors also discovered that social isolation reduced myelination in prefrontal cortex, replicating a previously published result (Makinodan et al., 2012), and additionally found that social isolation reduced expression of endothelin by endothelial cells. An intranasal endothelin receptor agonist was sufficient to rescue the social deprivation-associated myelination defect, consistent with the possibility that activitydependent myelination requires activation of EDNRB receptors on oligodendrocytes. Intriguingly, mice with oligodendrocytespecific loss of EDNRB were less sociable than wildtype siblings,

A
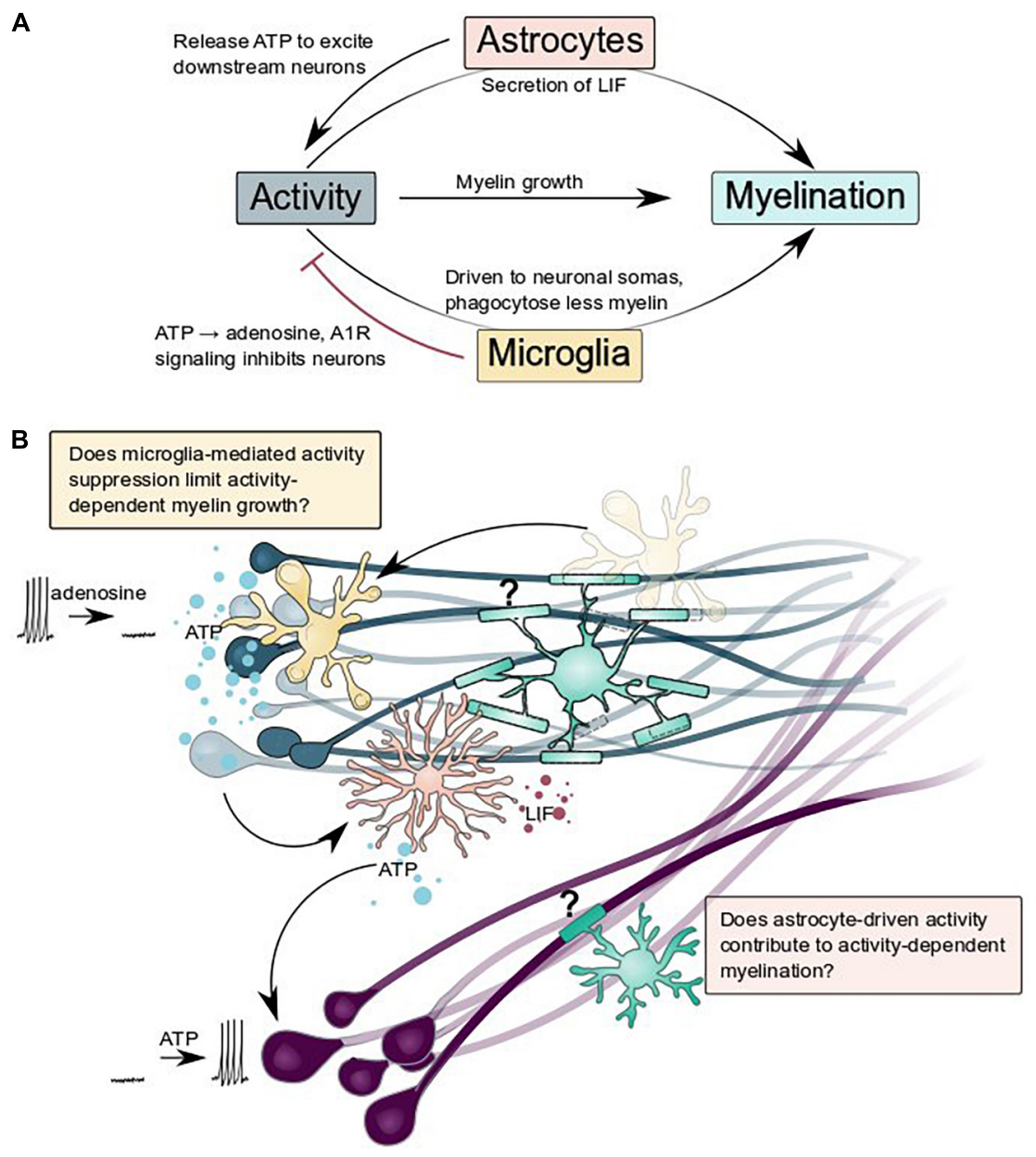

FIGURE 4 | Astrocytes and microglia regulate and are regulated by neuronal activity: what are the consequences for activity-dependent myelination? (A) Summary schematic of interactions between astrocytes, microglia, neurons, and myelination described by Ishibashi et al. (2006), Badimon et al. (2020), Ma et al. (2016), and Hughes and Appel (2020). (B) Does glial regulation of neuronal activity change activity-dependent myelination? Does microglial suppression of activity (blue neurons) and astrocytic release of ATP to excite nearby neurons (purple) contribute to activity-dependent myelination? 
raising the possibility that endothelin signaling-dependent myelination promotes social behavior (Swire et al., 2019).

\section{ON THE HORIZON: GLIAL REGULATION OF AND BY NEURONAL ACTIVITY SHAPES DOWNSTREAM ACTIVITY-DEPENDENT MYELINATION}

Each glial cell type that I have discussed thus far regulates oligodendrocyte development, but are additionally regulated by and can regulate neuronal activity. How does modulation by and of neuronal activity impact myelination? Suppression and stimulation of activity in sparse axons changes the growth of myelin on those axons, ostensibly in a sheathor oligodendrocyte-autonomous manner (Hines et al., 2015; Mensch et al., 2015; Wake et al., 2015; Koudelka et al., 2016; Mitew et al., 2018). How, then, does glial manipulation of axonal activity modulate the potential for activity-dependent myelination? Additionally, how does neuronal signaling to glia impact glial interactions with myelin (Figure 4)? These questions have been difficult to investigate because they require the inclusion and manipulation of multiple cell types and additional controls to isolate interactions of interest. Despite these challenges, such holistic investigations have begun to teach us how cell-cell interactions that have been identified by reductionist approaches interact with and moderate each other in the context of the whole brain (Liddelow et al., 2017; Geraghty et al., 2019; Gibson et al., 2019; Forbes et al., 2020). I conclude this review by raising questions that integrative approaches are now poised to tackle.

Glial cells can manipulate neuronal activity, both chronically and acutely. By participating in developmental synapse formation and refinement, glia broadly limit the range of activity that is possible within a nervous system. Emerging evidence suggests that glia can also act on much shorter timescales to flexibly modify activity. Astrocytes can increase activity, coupling the activity of populations of non-synaptically connected neurons via ATP secretion or other processes that occur downstream of intracellular calcium elevations (Ma et al., 2016; Mu et al., 2019). Might such synchronization of activity between disconnected neuronal populations configure similar activitydependent myelination? Additionally, microglia can suppress

\section{REFERENCES}

Adams, K. L., Riparini, G., Banerjee, P., Breur, M., Bugiani, M., and Gallo, V. (2020). Endothelin-1 signaling maintains glial progenitor proliferation in the postnatal subventricular zone. Nat. Commun. 11, 1-17. doi: 10.1038/s41467020-16028-8

Ainger, K., Avossa, D., Morgan, F., Hill, S. J., Barry, C., Barbarese, E., et al. (1993). Transport and localization of exogenous myelin basic protein mRNA microinjected into oligodendrocytes. J. Cell Biol. 123, 431-441. doi: 10.1083/ jcb.123.2.431

Albrecht, P. J., Murtie, J. C., Ness, J. K., Redwine, J. M., Enterline, J. R., Armstrong, R. C., et al. (2003). Astrocytes produce CNTF during the remyelination phase neuronal activity, presumably via ATP hydrolysis and A1R signaling at somatic contacts on neurons (Li et al., 2012; Eyo et al., 2014; Badimon et al., 2020; Cserép et al., 2020). Does this suppression limit activity-dependent myelin growth in brain regions where microglia are particularly enriched? Finally, an emerging body of work implicates oligodendrocytes, astrocytes, and the vasculature in providing metabolic support for axons (Nave, 2010; Fünfschilling et al., 2012; Lee et al., 2012; Saab et al., 2016; Nortley and Attwell, 2017; Meyer et al., 2018; Philippot et al., 2021; Philips et al., 2021), enabling sustained neuronal activity and function. Intriguingly, fuel sources and types vary between brain regions (Meyer et al., 2018) and astrocytes might be particularly important for providing trophic support during development (Philips et al., 2021). In addition to glial control of neuronal activity, glial cells are also altered by activity and this may change how they interact with myelin. For example, astrocytes responded to ATP released by active neurons by secreting leukemia inhibitory factor (LIF) which could promote myelination (Ishibashi et al., 2006). In our recent paper, we found that microglia contacted active neuronal somas more frequently and phagocytosed less myelin from axons (Hughes and Appel, 2020). Together, the interplay of individual glial cell types with neurons and with each other may tune glial function and neuronal activity to optimize neural circuit function.

\section{AUTHOR CONTRIBUTIONS}

ANH conceptualized the review and wrote and illustrated the manuscript.

\section{FUNDING}

My graduate research and training were supported by National Science Foundation Graduate Research Fellowship DGE1553798 and National Institutes of Health grant NS095679 and a gift from the Gates Frontiers Fund to Bruce Appel.

\section{ACKNOWLEDGMENTS}

I am grateful to members of the Appel lab, and Nicholas George, for helpful discussion and comments on the manuscript.

of viral-induced spinal cord demyelination to stimulate FGF-2 production. Neurobiol. Dis. 13, 89-101. doi: 10.1016/S0969-9961(03)00019-6

Almeida, R., and Lyons, D. (2016). Oligodendrocyte development in the absence of their target axons in vivo. PLoS One 11:e0164432. doi: 10.1371/journal.pone. 0164432

Almeida, R. G., and Lyons, D. A. (2017). On myelinated axon plasticity and neuronal circuit formation and function. J. Neurosci. 37, 10023-10034. doi: 10.1523/JNEUROSCI.3185-16.2017

Amur-Umarjee, S., Schonmann, V., and Campagnoni, A. T. (1997). Neuronal regulation of myelin basic protein mrna translocation in oligodendrocytes is mediated by platelet-derived growth factor. Dermatology 19, 143-151. doi: 10 . $1159 / 000111200$ 
Amur-Umarjee, S., Phan, T., and Campagnoni, A. T. (1993). Myelin basic protein mRNA translocation in oligodendrocytes is inhibited by astrocytes in vitro. J. Neurosci. Res. 36, 99-110. doi: 10.1002/jnr.490360111

Arnett, H. A., Mason, J., Marino, M., Suzuki, K., Matsushima, G. K., and Ting, J. P. Y. (2001). TNF $\alpha$ promotes proliferation of oligodendrocyte progenitors and remyelination. Nat. Neurosci. 4, 1116-1122. doi: 10.1038/nn738

Bacmeister, C. M., Barr, H. J., McClain, C. R., Thornton, M. A., Nettles, D., Welle, C. G., et al. (2020). Motor learning promotes remyelination via new and surviving oligodendrocytes. Nat. Neurosci. 23, 819-831. doi: 10.1038/s41593020-0637-3

Badimon, A., Strasburger, H. J., Ayata, P., Chen, X., Nair, A., Ikegami, A., et al. (2020). Negative feedback control of neuronal activity by microglia. Nature 586 , 417-423. doi: 10.1038/s41586-020-2777-8

Baerwald, K. D., and Popko, B. (1998). Developing and mature oligodendrocytes respond differently to the immune cytokine interferon-gamma. J. Neurosci. Res. $52,230-239$.

Baraban, M., Koudelka, S., and Lyons, D. A. (2018). Ca2+ activity signatures of myelin sheath formation and growth in vivo. Nat. Neurosci. 21, 19-23. doi: 10.1038/s41593-017-0040-x

Barnett, S. C., and Linington, C. (2013). Myelination: do astrocytes play a role? Neuroscientist 19, 442-450. doi: 10.1177/1073858412465655

Baror, R., Neumann, B., Segel, M., Chalut, K. J., Fancy, S. P. J., Schafer, D. P., et al. (2019). Transforming growth factor-beta renders ageing microglia inhibitory to oligodendrocyte generation by CNS progenitors. Glia 67, 1374-1384. doi: $10.1002 /$ glia.23612

Barres, B. A., Burne, J. F., Holtmann, B., Thoenen, H., Sendtner, M., and Raff, M. C. (1996). Ciliary neurotrophic factor enhances the rate of oligodendrocyte generation. Mol. Cell. Neurosci. 8, 146-156. doi: 10.1006/mcne.1996.0053

Barres, B. A., and Raff, M. C. (1993). Proliferation of oligodendrocyte precursor cells depends on electrical activity in axons. Nature 361, 258-260. doi: 10.1038/ $361258 \mathrm{a} 0$

Barres, B. A., Schmid, R., Sendnter, M., and Raff, M. C. (1993). Multiple extracellular signals are required for long-term oligodendrocyte survival. Development 118, 283-295.

Battefeld, A., Klooster, J., and Kole, M. H. P. P. (2016). Myelinating satellite oligodendrocytes are integrated in a glial syncytium constraining neuronal high-frequency activity. Nat. Commun. 7:11298. doi: 10.1038/ncomms1 1298

Bayraktar, O. A., Fuentealba, L. C., Alvarez-Buylla, A., and Rowitch, D. H. (2015). Astrocyte development and heterogeneity. Cold Spring Harb. Perspect. Biol. 7:a020362. doi: 10.1101/cshperspect.a020362

Bechler, M. E., Byrne, L., and French-Constant, C. (2015). CNS myelin sheath lengths are an intrinsic property of oligodendrocytes. Curr. Biol. 25, 2411-2416. doi: 10.1016/j.cub.2015.07.056

Bennett, M. L., Bennett, F. C., Liddelow, S. A., Ajami, B., Zamanian, J. L., Fernhoff, N. B., et al. (2016). New tools for studying microglia in the mouse and human CNS. Proc. Natl. Acad. Sci. 113, E1738-E1746. doi: 10.1073/pnas.1525528113

Berghoff, S. A., Spieth, L., Sun, T., Hosang, L., Schlaphoff, L., Depp, C., et al. (2021). Microglia facilitate repair of demyelinated lesions via post-squalene sterol synthesis. Nat. Neurosci. 24, 47-60. doi: 10.1038/s41593-020-00757-6

Bergles, D. E., and Richardson, W. D. (2016). Oligodendrocyte development and plasticity. Cold Spring Harb. Perspect. Biol. 8:a020453. doi: 10.1101/cshperspect. a020453

Birey, F., Kloc, M., Chavali, M., Hussein, I., Wilson, M., Christoffel, D. J., et al. (2015). Genetic and stress-induced loss of NG2 glia triggers emergence of depressive-like behaviors through reduced secretion of FGF2. Neuron 88, 941956. doi: 10.1016/j.neuron.2015.10.046

Butzkueven, H., Zhang, J. G., Soilu-Hanninen, M., Hochrein, H., Chionh, F., Shipham, K. A., et al. (2002). LIF receptor signaling limits immune-mediated demyelination by enhancing oligodendrocyte survival. Nat. Med. 8, 613-619. doi: $10.1038 / \mathrm{nm} 0602-613$

Camargo, N., Goudriaan, A., van Deijk, A. L. F., Otte, W. M., Brouwers, J. F., Lodder, H., et al. (2017). Oligodendroglial myelination requires astrocytederived lipids. PLoS Biol. 15:1002605. doi: 10.1371/journal.pbio.1002605

Cheadle, L., Rivera, S. A., Phelps, J. S., Ennis, K. A., Stevens, B., Burkly, L. C., et al. (2020). Sensory experience engages microglia to shape neural connectivity through a non-phagocytic mechanism. Neuron 108, 451-468. doi: 10.1016/j. neuron.2020.08.002
Chen, W., He, B., Tong, W., Zeng, J., and Zheng, P. (2019). Astrocytic insulin-like growth factor-1 protects neurons against excitotoxicity. Front. Cell. Neurosci. 13:298. doi: 10.3389/fncel.2019.00298

Chew, L.-J., King, W. C., Kennedy, A., and Gallo, V. (2005). Interferon- $\gamma$ inhibits cell cycle exit in differentiating oligodendrocyte progenitor cells. Glia 52, 127-143. doi: 10.1002/glia.20232

Choe, Y., Huynh, T., and Pleasure, S. J. (2014). Migration of oligodendrocyte progenitor cells is controlled by transforming growth factor $\beta$ family proteins during corticogenesis. J. Neurosci. 34, 14973-14983. doi: 10.1523/JNEUROSCI. 1156-14.2014

Coull, J. A. M. M., Beggs, S., Boudreau, D., Boivin, D., Tsuda, M., Inoue, K., et al. (2005). BDNF from microglia causes the shift in neuronal anion gradient underlying neuropathic pain. Nature 438, 1017-1021. doi: 10.1038/ nature 04223

Cserép, C., Pósfai, B., Lénárt, N., Fekete, R., László, Z. I., Lele, Z., et al. (2020). Microglia monitor and protect neuronal function through specialized somatic purinergic junctions. Washington, D.C: American Association for the Advancement of Science.

De Biase, L. M., Schuebel, K. E., Fusfeld, Z. H., Jair, K., Hawes, I. A., Cimbro, R., et al. (2017). Local cues establish and maintain region-specific phenotypes of basal ganglia microglia. Neuron 95, 341-356. doi: 10.1016/j.neuron.2017.06.020

De La Fuente, A. G., Lange, S., Silva, M. E., Gonzalez, G. A., Tempfer, H., van Wijngaarden, P., et al. (2017). Pericytes stimulate oligodendrocyte progenitor cell differentiation during CNS remyelination. Cell Rep. 20, 1755-1764. doi: 10.1016/j.celrep.2017.08.007

Demerens, C., Stankoff, B., Logak, M., Angladet, P., Allinquantt, B., Couraud, F., et al. (1996). Induction of myelination in the central nervous system by electrical activity. Neurobiology 93, 9887-9892.

Didier, N., Romero, I. A., Créminon, C., Wijkhuisen, A., Grassi, J., and Mabondzo, A. (2004). Secretion of interleukin- $1 \beta$ by astrocytes mediates endothelin- 1 and tumour necrosis factor- $\alpha$ effects on human brain microvascular endothelial cell permeability. J. Neurochem. 86, 246-254. doi: 10.1046/j.1471-4159.2003.0 1829.x

Dimas, P., Montani, L., Pereira, J. A., Moreno, D., Trötzmüller, M., Gerber, J., et al. (2019). Cns myelination and remyelination depend on fatty acid synthesis by oligodendrocytes. Elife 8:e44702. doi: 10.7554/eLife.44702

Djannatian, M., Timmler, S., Arends, M., Luckner, M., Weil, M. T., Alexopoulos, I., et al. (2019). Two adhesive systems cooperatively regulate axon ensheathment and myelin growth in the CNS. Nat. Commun. 10:4794. doi: 10.1038/s41467019-12789-z

Djannatian, M., Weikert, U., Safaiyan, S., Wrede, C., Kislinger, G., Ruhwedel, T., et al. (2021). ). Myelin biogenesis is associated with pathological ultrastructure that is resolved by microglia during development 23 4. bioRxiv 2021:429485. doi: 10.1101/2021.02.02.429485

Duncan, I. D., Radcliff, A. B., Heidari, M., Kidd, G., August, B. K., and Wierenga, L. A. (2018). The adult oligodendrocyte can participate in remyelination. Proc. Natl. Acad. Sci. U. S. A. 115, E11807-E11816. doi: 10.1073/pnas.1808064115

Dutta, D. J., Woo, D. H., Lee, P. R., Pajevic, S., Bukalo, O., Huffman, W. C., et al. (2018). Regulation of myelin structure and conduction velocity by perinodal astrocytes. Proc. Natl. Acad. Sci. U. S. A. 115, 11832-11837. doi: 10.1073/pnas. 1811013115

Elazar, N., Vainshtein, A., Golan, N., Vijayaragavan, B., Schaeren-Wiemers, N., Eshed-Eisenbach, Y., et al. (2018). Axoglial adhesion by cadm4 regulates CNS myelination. Neuron 101, 224-231. doi: 10.1016/J.NEURON.2018.11.032

Elazar, N., Vainshtein, A., Rechav, K., Tsoory, M., Eshed-Eisenbach, Y., and Peles, E. (2019). Coordinated internodal and paranodal adhesion controls accurate myelination by oligodendrocytes. J. Cell Biol. 218, 2887-2895. doi: 10.1083/JCB. 201906099

Elbaz, B., and Popko, B. (2019). Molecular control of oligodendrocyte development. Trends Neurosci. 42, 263-277. doi: 10.1016/j.tins.2019.01.002

Elmore, M. R. P., Najafi, A. R., Koike, M. A., Dagher, N. N., Spangenberg, E. E., Rice, R. A., et al. (2014). Colony-Stimulating factor 1 receptor signaling is necessary for microglia viability, unmasking a microglia progenitor cell in the adult brain. Neuron 82, 380-397. doi: 10.1016/J.NEURON.2014.02.040

Erblich, B., Zhu, L., Etgen, A. M., Dobrenis, K., and Pollard, J. W. (2011). Absence of colony stimulation factor-1 receptor results in loss of microglia, disrupted brain development and olfactory deficits. PLoS One 6:e26317. doi: 10.1371/ journal.pone.0026317 
Espitia Pinzon, N., van Mierlo, H., de Jonge, J. C., Brevé, J. J. P., Bol, J. G. J. M., Drukarch, B., et al. (2019). Tissue transglutaminase promotes early differentiation of oligodendrocyte progenitor cells. Front. Cell. Neurosci. 13:281. doi: $10.3389 /$ fncel.2019.00281

Etxeberria, A., Hokanson, K. C., Dao, D. Q., Mayoral, S. R., Mei, F., Redmond, S. A., et al. (2016). Dynamic modulation of myelination in response to visual stimuli alters optic nerve conduction velocity. J. Neurosci. 36, 6937-6948. doi: 10.1523/JNEUROSCI.0908-16.2016

Eyo, U. B., Peng, J., Swiatkowski, P., Mukherjee, A., Bispo, A., and Wu, L.-J. (2014). Neuronal hyperactivity recruits microglial processes via neuronal nmda receptors and microglial P2Y12 receptors after status epilepticus. J Neurosci. 34, 10528-10540. doi: 10.1523/JNEUROSCI.0416-14.2014

Fields, R. D. (2015). A new mechanism of nervous system plasticity: activitydependent myelination. Nat. Publ. Gr. 16, 756-767. doi: 10.1038/nrn4023

Forbes, T. A., Goldstein, E. Z., Dupree, J. L., Jablonska, B., Scafidi, J., Adams, K. L., et al. (2020). Environmental enrichment ameliorates perinatal brain injury and promotes functional white matter recovery. Nat. Commun. 11, 1-17. doi: 10.1038/s41467-020-14762-7

Fortin, D., Rom, E., Sun, H., Yayon, A., and Bansal, R. (2005). Distinct fibroblast growth factor (FGF)/FGF receptor signaling pairs initiate diverse cellular responses in the oligodendrocyte lineage. J. Neurosci. 25, 7470-7479. doi: 10. 1523/JNEUROSCI.2120-05.2005

Fulmer, C. G., Vondran, M. W., Stillman, A. A., Huang, Y., Hempstead, B. L., and Dreyfus, C. F. (2014). Astrocyte-derived BDNF supports myelin protein synthesis after cuprizone-induced demyelination. J. Neurosci. 34, 8186-8196. doi: 10.1523/JNEUROSCI.4267-13.2014

Fünfschilling, U., Supplie, L. M., Mahad, D., Boretius, S., Saab, A. S., Edgar, J., et al. (2012). Glycolytic oligodendrocytes maintain myelin and long-term axonal integrity. Nature 485, 517-521. doi: 10.1038/nature1 1007

Garcia, M. A., and Zuchero, J. B. (2019). Anchors away: glia-neuron adhesion regulates myelin targeting and growth. Dev. Cell 51, 659-661. doi: 10.1016/j. devcel.2019.11.018

Geirsdottir, L., David, E., Keren-Shaul, H., Weiner, A., Bohlen, S. C., Neuber, J., et al. (2019). Cross-species single-cell analysis reveals divergence of the primate microglia program. Cell 179, 1609-1622. doi: 10.1016/j.cell.2019. 11.010

Geraghty, A. C., Gibson, E. M., Ghanem, R. A., Greene, J. J., Ocampo, A., Goldstein, A. K., et al. (2019). Loss of adaptive myelination contributes to methotrexate chemotherapy-related cognitive impairment. Neuron 103, 250-265. doi: 10. 1016/j.neuron.2019.04.032

Gibson, E. M., Nagaraja, S., Ocampo, A., Tam, L. T., Wood, L. S., Pallegar, P. N., et al. (2019). Methotrexate chemotherapy induces persistent Tri-glial dysregulation that underlies chemotherapy-related cognitive impairment. Cell 176, 43-55. doi: 10.1016/J.CELL.2018.10.049

Gibson, E. M., Purger, D., Mount, C. W., Goldstein, A. K., Lin, G. L., Wood, L. S., et al. (2014). Neuronal activity promotes oligodendrogenesis and adaptive myelination in the mammalian brain. Science 344:1252304. doi: 10.1126/ science. 1252304

Giera, S., Luo, R., Ying, Y., Ackerman, S. D., Jeong, S. J., Stoveken, H. M., et al. (2018). Microglial transglutaminase-2 drives myelination and myelin repair via GPR56/ADGRG1 in oligodendrocyte precursor cells. Elife 7:e33385. doi: 10.7554/eLife. 33385

Ginhoux, F., Greter, M., Leboeuf, M., Nandi, S., See, P., Gokhan, S., et al. (2010). Fate mapping analysis reveals that adult microglia derive from primitive macrophages. Science 330, 841-845. doi: 10.1126/science.1194637

Gollan, L., Salomon, D., Salzer, J. L., and Peles, E. (2003). Caspr regulates the processing of contactin and inhibits its binding to neurofascin. J. Cell Biol. 163, 1213-1218. doi: 10.1083/jcb.200309147

Gomes, C., Ferreira, R., George, J., Sanches, R., Rodrigues, D. I., Gonçalves, N., et al. (2013). Activation of microglial cells triggers a release of brain-derived neurotrophic factor (BDNF) inducing their proliferation in an adenosine $\mathrm{A} 2 \mathrm{~A}$ receptor-dependent manner: A2A receptor blockade prevents BDNF release and proliferation of microglia. J. Neuroinflammation 10:780. doi: 10.1186/17422094-10-16

Grassivaro, F., Menon, R., Acquaviva, M., Ottoboni, L., Ruffini, F., Andrea Bergamaschi, X., et al. (2020). Convergence between microglia and peripheral macrophages phenotype during development and neuroinflammation. J. Neurosci. 40, 784-795. doi: 10.1523/JNEUROSCI.1523-19.2019
Green, K. N., and Hume, D. A. (2021). On the utility of CSF1R inhibitors. Proc. Natl. Acad. Sci. U. S. A. 118:e2019695118. doi: 10.1073/pnas.2019695118

Gunner, G., Cheadle, L., Johnson, K. M., Ayata, P., Badimon, A., Mondo, E., et al. (2019). Sensory lesioning induces microglial synapse elimination via ADAM10 and fractalkine signaling. Nat. Neurosci. 22, 1075-1088. doi: 10.1038/s41593019-0419-y

Hagemeyer, N., Hanft, K.-M. M., Akriditou, M.-A. A., Unger, N., Park, E. S., Stanley, E. R., et al. (2017). Microglia contribute to normal myelinogenesis and to oligodendrocyte progenitor maintenance during adulthood. Acta Neuropathol. 134, 441-458. doi: 10.1007/s00401-017-1747-1

Hammond, T. R., Dufort, C., Dissing-Olesen, L., Giera, S., Young, A., Wysoker, A., et al. (2019). Single-Cell RNA sequencing of microglia throughout the mouse lifespan and in the injured brain reveals complex cell-state changes. Immunity 50, 253-271. doi: 10.1016/j.immuni.2018.11.004

Hart, I. K., Richardson, W. D., Heldin, C.-H., Westermark, B., and Raff, M. C. (1989). PDGF receptors on cells of the oligodendrocyte-type-2 astrocyte (O-2A) cell lineage. Development 105, 595-603.

Hartline, D. K., and Colman, D. R. (2007). Rapid conduction and the evolution of giant axons and myelinated fibers. Curr. Biol. 17, 29-35. doi: 10.1016/j.cub. 2006.11.042

Herbert, A. L., Fu, M. M., Drerup, C. M., Gray, R. S., Harty, B. L., Ackerman, S. D., et al. (2017). Dynein/dynactin is necessary for anterograde transport of Mbp mRNA in oligodendrocytes and for myelination in vivo. Proc. Natl. Acad. Sci. U. S. A. 114, E9153-E9162. doi: 10.1073/pnas.1711088114

Hines, J. H., Ravanelli, A. M., Schwindt, R., Scott, E. K., and Appel, B. (2015). Neuronal activity biases axon selection for myelination in vivo. Nat. Neurosci. 18, 683-689. doi: 10.1038/nn.3992

Holtschke, T., Löhler, J., Kanno, Y., Fehr, T., Giese, N., Rosenbauer, F., et al. (1996). Immunodeficiency and chronic myelogenous leukemia-like syndrome in mice with a targeted mutation of the ICSBP gene. Cell 87, 307-317. doi: 10.1016/S0092-8674(00)81348-3

Huang, W., Bai, X., Meyer, E., and Scheller, A. (2020). Acute brain injuries trigger microglia as an additional source of the proteoglycan NG2. Acta Neuropathol. Commun. 8:146. doi: 10.1186/s40478-020-01016-2

Hughes, A. N., and Appel, B. (2019). Oligodendrocytes express synaptic proteins that modulate myelin sheath formation. Nat. Commun. 10, 4125. doi: 10.1038/ s41467-019-12059-y

Hughes, A. N., and Appel, B. (2020). Microglia phagocytose myelin sheaths to modify developmental myelination. Nat. Neurosci. 23, 1055-1066. doi: 10.1038/ s41593-020-0654-2

Hughes, E. G., and Appel, B. (2016). The cell biology of CNS myelination. Curr. Opin. Neurobiol. 39, 93-100. doi: 10.1016/j.conb.2016.04.013

Hughes, E. G., Kang, S. H., Fukaya, M., and Bergles, D. E. (2013). Oligodendrocyte progenitors balance growth with self-repulsion to achieve homeostasis in the adult brain. Nat. Neurosci. 16, 668-676. doi: 10.1038/nn.3390

Ishibashi, T., Dakin, K. A., Stevens, B., Lee, P. R., Kozlov, S. V., Stewart, C. L., et al. (2006). Astrocytes promote myelination in response to electrical impulses. Neuron 49, 823-832. doi: 10.1016/j.neuron.2006.02.006

Jahn, O., Siems, S. B., Kusch, K., Hesse, D., Jung, R. B., Liepold, T., et al. (2020). The CNS myelin proteome: deep profile and persistence after post-mortem delay. Front. Cell. Neurosci. 14:239. doi: 10.3389/fncel.2020.00239

Kaiser, T., and Feng, G. (2019). Tmem119-EGFP and Tmem119-creERT2 transgenic mice for labeling and manipulating microglia. eNeuro 6:ENEURO.448-ENEURO.418. doi: 10.1523/ENEURO.0448-18.2019

Kessaris, N., Fogarty, M., Iannarelli, P., Grist, M., Wegner, M., and Richardson, W. D. (2006). Competing waves of oligodendrocytes in the forebrain and postnatal elimination of an embryonic lineage. Nat. Neurosci. 9, 173-179. doi: $10.1038 / \mathrm{nn} 1620$

Kirby, B. B., Takada, N., Latimer, A. J., Shin, J., Carney, T. J., Kelsh, R. N., et al. (2006). In vivo time-lapse imaging shows dynamic oligodendrocyte progenitor behavior during zebrafish development. Nat. Neurosci. 9, 1506-1511. doi: 10. 1038/nn1803

Kirby, E. D., Muroy, S. E., Sun, W. G., Covarrubias, D., Leong, M. J., Barchas, L. A., et al. (2013). Acute stress enhances adult rat hippocampal neurogenesis and activation of newborn neurons via secreted astrocytic FGF2. Elife 2:362. doi: 10.7554/eLife.00362

Klingseisen, A., Ristoiu, A. M., Kegel, L., Sherman, D. L., Rubio-Brotons, M., Almeida, R. G., et al. (2019). Oligodendrocyte neurofascin independently 
regulates both myelin targeting and sheath growth in the CNS. Dev. Cell 51, 730-744. doi: 10.1016/j.devcel.2019.10.016

Koudelka, S., Voas, M. G. G., Almeida, R. G. G., Baraban, M., Soetaert, J., Meyer, M. P. P., et al. (2016). Individual neuronal subtypes exhibit diversity in cns myelination mediated by synaptic vesicle release. Curr. Biol. 26, 1447-1455. doi: 10.1016/j.cub.2016.03.070

Krasnow, A. M., Ford, M. C., Valdivia, L. E., Wilson, S. W., and Attwell, D. (2018). Regulation of developing myelin sheath elongation by oligodendrocyte calcium transients in vivo. Nat. Neurosci. 21, 24-28. doi: 10.1038/s41593-0170031-y

Kuboyama, K., Fujikawa, A., Masumura, M., Suzuki, R., Matsumoto, M., and Noda, M. (2012). Protein tyrosine phosphatase receptor type $\mathrm{Z}$ negatively regulates oligodendrocyte differentiation and myelination. PLoS One 7:0048797. doi: 10. 1371/journal.pone.0048797

Kuboyama, K., Fujikawa, A., Suzuki, R., and Noda, M. (2015). Inactivation of protein tyrosine phosphatase receptor type $\mathrm{Z}$ by pleiotrophin promotes remyelination through activation of differentiation of oligodendrocyte precursor cells. J. Neurosci. 35, 12162-12171. doi: 10.1523/JNEUROSCI.212715.2015

Kuboyama, K., Fujikawa, A., Suzuki, R., Tanga, N., and Noda, M. (2016). Role of chondroitin sulfate (CS) modification in the regulation of proteintyrosine phosphatase receptor type Z (PTPRZ) activity: Pleiotrophin-PTPRZ-A signaling is involved in oligodendrocyte differentiation. J. Biol. Chem. 291, 18117-18128. doi: 10.1074/jbc.M116.742536

Laferla, F. M., Sugarman, M. C., Lane, T. E., and Leissring, M. A. (2000). Regional hypomyelination and dysplasia in transgenic mice with astrocyte-directed expression of interferon- $\gamma$. J. Mol. Neurosci. 15, 45-59. doi: 10.1385/JMN:15: $1: 45$

Lau, L. T., and Yu, A. C. H. (2001). Astrocytes produce and release interleukin1 , interleukin-6, tumor necrosis factor alpha and interferon-gamma following traumatic and metabolic injury. J. Neurotrauma 18, 351-359. doi: 10.1089/ 08977150151071035

Lee, Y., Morrison, B. M., Li, Y., Lengacher, S., Farah, M. H., Hoffman, P. N., et al. (2012). Oligodendroglia metabolically support axons and contribute to neurodegeneration. Nature 487, 443-448. doi: 10.1038/nature11314

Lei, F., Cui, N., Zhou, C., Chodosh, J., Vavvas, D. G., and Paschalis, E. I. (2020). CSF1R inhibition by a small-molecule inhibitor is not microglia specific; affecting hematopoiesis and the function of macrophages. Proc. Natl. Acad. Sci. U. S. A. 117, 23336-23338. doi: 10.1073/pnas.1922788117

Li, Q., Cheng, Z., Zhou, L., Darmanis, S., Neff, N. F., Okamoto, J., et al. (2019). Developmental heterogeneity of microglia and brain myeloid cells revealed by deep single-cell RNA sequencing. Neuron 101, 207-223. doi: 10.1016/J. NEURON.2018.12.006

Li, T., Chiou, B., Gilman, C. K., Luo, R., Koshi, T., Yu, D., et al. (2020). A splicing isoform of GPR56 mediates microglial synaptic refinement via phosphatidylserine binding. EMBO J. 39:e104136. doi: 10.15252/embj. 2019104136

Li, Y., Du, X., Liu, C., Wen, Z.-L., and Du, J. (2012). Reciprocal regulation between resting microglial dynamics and neuronal activity in vivo. Dev. Cell 23, 1189-1202. doi: 10.1016/j.devcel.2012.10.027

Liddelow, S. A., Guttenplan, K. A., Clarke, L. E., Bennett, F. C., Bohlen, C. J., Schirmer, L., et al. (2017). Neurotoxic reactive astrocytes are induced by activated microglia. Nature 541, 481-487. doi: 10.1038/nature21029

Lin, W., Kemper, A., Dupree, J. L., Harding, H. P., Ron, D., and Popko, B. (2006). Interferon- $\gamma$ inhibits central nervous system remyelination through a process modulated by endoplasmic reticulum stress. Brain 129, 1306-1318. doi: 10. 1093/brain/awl044

Liu, P., Du, J., and He, C. (2013). Developmental pruning of early-stage myelin segments during CNS myelination in vivo. Cell Res. 23, 962-964. doi: 10.1038/ cr.2013.62

Liu, X., Mashour, G. A., Webster, H. D., and Kurtz, A. (1998). Basic FGF and FGF receptor 1 are expressed in microglia during experimental autoimmune encephalomyelitis: temporally distinct expression of midkine and pleiotrophen. Glia 24, 390-397.

Liu, Y., Hammel, G., Shi, M., Cheng, Z., Zivkovic, S., Wang, X., et al. (2021). Myelin debris stimulates NG2/CSPG4 expression in bone marrow-derived macrophages in the injured spinal cord. Front. Cell. Neurosci. 15:1827. doi: $10.3389 /$ fncel.2021.651827
Liu, Y. U., Ying, Y., Li, Y., Eyo, U. B., Chen, T., Zheng, J., et al. (2019). Neuronal network activity controls microglial process surveillance in awake mice via norepinephrine signaling. Nat. Neurosci. 22, 1771-1781. doi: 10.1038/s41593019-0511-3

Lundgaard, I., Luzhynskaya, A., Stockley, J. H., Wang, Z., Evans, K. A., Swire, M., et al. (2013). Neuregulin and BDNF induce a switch to NMDA receptordependent myelination by oligodendrocytes. PLoS Biol. 11:e1001743. doi: 10 . 1371/journal.pbio.1001743

Lundgaard, I., Osório, M. J., Kress, B. T., Sanggaard, S., and Nedergaard, M. (2014). White matter astrocytes in health and disease. Neuroscience 276, 161-173. doi: 10.1016/j.neuroscience.2013.10.050

Lutz, S. E., Zhao, Y., Gulinello, M., Lee, S. C., Raine, C. S., and Brosnan, C. F. (2009). Deletion of astrocyte connexins 43 and 30 Leads to a dysmyelinating phenotype and hippocampal CA1 vacuolation. J Neurosci. 29, 7743-7752. doi: 10.1523/JNEUROSCI.0341-09.2009

Ma, Z., Stork, T., Bergles, D. E., and Freeman, M. R. (2016). Neuromodulators signal through astrocytes to alter neural circuit activity and behaviour. Nature 539, 428-432. doi: 10.1038/nature20145

Makinodan, M., Rosen, K. M., Ito, S., and Corfas, G. (2012). A critical period for social experience-dependent oligodendrocyte maturation and myelination. Science 337, 1357-1360. doi: 10.1126/science. 1220845

Mangin, J. M., and Gallo, V. (2011). The curious case of NG2 cells: transient trend or game changer? ASN Neuro 3, 37-49. doi: 10.1042/AN20110001

Marisca, R., Hoche, T., Agirre, E., Hoodless, L. J., Barkey, W., Auer, F., et al. (2020). Functionally distinct subgroups of oligodendrocyte precursor cells integrate neural activity and execute myelin formation. Nat. Neurosci. 23, 363-374. doi: 10.1038/s41593-019-0581-2

Marques, S., Zeisel, A., Codeluppi, S., van Bruggen, D., Mendanha Falcão, A., Xiao, L., et al. (2016). Oligodendrocyte heterogeneity in the mouse juvenile and adult central nervous system. Science 352, 1326-1329. doi: 10.1126/science.aaf 6463

Mathews, E. S., Mawdsley, D. J., Walker, M., Hines, J. H., Pozzoli, M., and Appel, B. (2014). Mutation of 3-hydroxy-3-methylglutaryl CoA synthase I reveals requirements for isoprenoid and cholesterol synthesis in oligodendrocyte migration arrest, axon wrapping, and myelin gene expression. J. Neurosci. 34, 3402-3412. doi: 10.1523/JNEUROSCI.4587-13.2014

Mauch, D. H., Nägier, K., Schumacher, S., Göritz, C., Müller, E. C., Otto, A., et al. (2001). CNS synaptogenesis promoted by glia-derived cholesterol. Science 294, 1354-1357. doi: 10.1126/science.294.5545.1354

Mcclain, C. R., Sim, F. J., and Goldman, S. A. (2012). Pleiotrophin suppression of receptor protein tyrosine phosphatase-/ maintains the self-renewal competence of fetal human oligodendrocyte progenitor cells. J Neurosci. 32, 15066-15075. doi: 10.1523/JNEUROSCI.1320-12.2012

McKenzie, I. A., Ohayon, D., Li, H., De Faria, J. P., Emery, B., Tohyama, K., et al. (2014). Motor skill learning requires active central myelination. Science 346, 318-322. doi: 10.1126/science. 1254960

McKinsey, G. L., Lizama, C. O., Keown-Lang, A. E., Niu, A., Santander, N., Larpthaveesarp, A., et al. (2020). A new genetic strategy for targeting microglia in development and disease. Elife 9, 1-34. doi: 10.7554/eLife.54590

McNamara, N. B., and Miron, V. E. (2020). Microglia in developing white matter and perinatal brain injury. Neurosci. Lett. 714:134539. doi: 10.1016/j.neulet. 2019.134539

Mctigue, D. M., Horner, P. J., Stokes, B. T., and Gage, F. H. (1998). Neurotrophin3 and brain-derived neurotrophic factor induce oligodendrocyte proliferation and myelination of regenerating axons in the contused adult rat spinal cord. $J$ Neurosci. 18, 5354-5365.

Menichella, D. M., Majdan, M., Awatramani, R., Goodenough, D. A., Sirkowski, E., Scherer, S. S., et al. (2006). Genetic and physiological evidence that oligodendrocyte gap junctions contribute to spatial buffering of potassium released during neuronal activity. J. Neurosci. 26, 10984-10991. doi: 10.1523/ JNEUROSCI.0304-06.2006

Mensch, S., Baraban, M., Almeida, R., Czopka, T., Ausborn, J., El Manira, A., et al. (2015). Synaptic vesicle release regulates myelin sheath number of individual oligodendrocytes in vivo. Nat. Neurosci. 18, 628-630. doi: 10.1038/nn.3991

Messersmith, D. J., Murtie, J. C., Le, T. Q., Frost, E. E., and Armstrong, R. C. (2000). Fibroblast growth factor 2 (FGF2) and FGF receptor expression in an experimental demyelinating disease with extensive remyelination. J. Neurosci. Res. 62, 241-256. 
Meyer, N., Richter, N., Fan, Z., Siemonsmeier, G., Pivneva, T., Jordan, P., et al. (2018). Oligodendrocytes in the mouse corpus callosum maintain axonal function by delivery of glucose. Cell Rep. 22, 2383-2394. doi: 10.1016/j.celrep. 2018.02.022

Meyer-Franke, A., Shen, S., and Barres, B. A. (1999). Astrocytes induce oligodendrocyte processes to align with and adhere to axons. Cambridge: Academic Press Inc, doi: 10.1006/mcne.1999.0788

Mills, E. A., Davis, C. H. O., Bushong, E. A., Boassa, D., Kim, K.-Y. Y., Ellisman, M. H., et al. (2015). Astrocytes phagocytose focal dystrophies from shortening myelin segments in the optic nerve of xenopus laevis at metamorphosis. Proc. Natl. Acad. Sci. U. S. A. 112, 10509-10514. doi: 10.1073/pnas.15064 86112

Miron, V. E. (2017). Microglia-driven regulation of oligodendrocyte lineage cells, myelination, and remyelination. J. Leukoc. Biol. 101, 1103-1108. doi: 10.1189/ jlb.3RI1116-494R

Mitew, S., Gobius, I., Fenlon, L. R., McDougall, S. J., Hawkes, D., Xing, Y. L., et al. (2018). Pharmacogenetic stimulation of neuronal activity increases myelination in an axon-specific manner. Nat. Commun. 9:306. doi: 10.1038/s41467-01702719-2

Moidunny, S., Vinet, J., Wesseling, E., Bijzet, J., Shieh, C. H., van Ijzendoorn, S. C. D., et al. (2012). Adenosine A2B receptor-mediated leukemia inhibitory factor release from astrocytes protects cortical neurons against excitotoxicity. J. Neuroinflam. 9:684. doi: 10.1186/1742-2094-9-198

Mount, C. W., and Monje, M. (2017). Wrapped to adapt: experience-dependent myelination. Neuron 95, 743-756. doi: 10.1016/J.NEURON.2017.07.009

Mu, Y., Bennett, D. V., Rubinov, M., Narayan, S., Yang, C. T., Tanimoto, M., et al. (2019). Glia accumulate evidence that actions are futile and suppress unsuccessful behavior. Cell 178, 27-43. doi: 10.1016/j.cell.2019.05.050

Muro, E., Ekin Atilla-Gokcumen, G., and Eggert, U. S. (2014). Lipids in cell biology: how can we understand them better? Mol. Biol. Cell 25, 1819-1823. doi: 10.1091/mbc.E13-09-0516

Nagai, J., Yu, X., Papouin, T., Cheong, E., Freeman, M. R., Monk, K. R., et al. (2021). Behaviorally consequential astrocytic regulation of neural circuits. Neuron 109, 576-596. doi: 10.1016/j.neuron.2020.12.008

Nagy, B., Hovhannisyan, A., Barzan, R., Chen, T. J., and Kukley, M. (2017). Different patterns of neuronal activity trigger distinct responses of oligodendrocyte precursor cells in the corpus callosum. PLoS Biol. 15:e2001993. doi: 10.1371/journal.pbio.2001993

Nagy, J. I., Ionescu, A.-V., Lynn, B. D., and Rash, J. E. (2003). Coupling of astrocyte connexins $\mathrm{Cx} 26, \mathrm{Cx} 30, \mathrm{Cx} 43$ to oligodendrocyte $\mathrm{Cx} 29, \mathrm{Cx} 32, \mathrm{Cx} 47$ : implications from normal and connexin32 knockout mice. Glia 44, 205-218. doi: 10.1002/glia.10278

Nagy, J. I., and Rash, J. E. (2000). Connexins and gap junctions of astrocytes and oligodendrocytes in the CNS. Brain Res. Rev. 32, 29-44. doi: 10.1016/S01650173(99)00066- 1

Nakajima, K., Tohyama, Y., Kohsaka, S., and Kurihara, T. (2002). Ceramide activates microglia to enhance the production/secretion of brain-derived neurotrophic factor (BDNF) without induction of deleterious factors in vitro. Hoboken, NJ: John Wiley \& Sons, Ltd.

Nakazawa, T., Nakazawa, C., Matsubara, A., Noda, K., Hisatomi, T., She, H., et al. (2006). Neurobiology of disease tumor necrosis factor-mediates oligodendrocyte death and delayed retinal ganglion cell loss in a mouse model of glaucoma. J Neurosci. 26, 12633-12641. doi: 10.1523/JNEUROSCI.2801-06. 2006

Nash, B., Thomson, C. E., Linington, C., Arthur, A. T., McClure, J. D., Mcbride, M. W., et al. (2011). Functional duality of astrocytes in myelination. J. Neurosci. 31, 13028-13038. doi: 10.1523/JNEUROSCI.1449-11.2011

Nave, K. A. (2010). Myelination and the trophic support of long axons. Nat. Rev. Neurosci. 11, 275-283. doi: 10.1038/nrn2797

Nave, K.-A., and Werner, H. B. (2014). Myelination of the nervous system: mechanisms and functions. Annu. Rev. Cell Dev. Biol. 30, 503-533. doi: 10.1146/ annurev-cellbio-100913-013101

Nayak, D., Roth, T. L., and McGavern, D. B. (2014). Microglia development and function. Annu. Rev. Immunol. 32, 367-402. doi: 10.1146/annurev-immunol032713-120240

Nguyen, P. T., Dorman, L. C., Pan, S., Vainchtein, I. D., Han, R. T., Nakao-Inoue, H., et al. (2020). Microglial remodeling of the extracellular matrix promotes synapse plasticity. Cell 182, 388-403. doi: 10.1016/j.cell.2020.05.050
Nikolakopoulou, A. M., Montagne, A., Kisler, K., Dai, Z., Wang, Y., Huuskonen, M. T., et al. (2019). Pericyte loss leads to circulatory failure and pleiotrophin depletion causing neuron loss. Nat. Neurosci. 22, 1089-1098. doi: 10.1038/ s41593-019-0434-z

Noble, M., Murray, K., Stroobant, P., Waterfield, M. D., and Riddle, P. (1988). Platelet-derived growth factor promotes division and motility and inhibits premature differentiation of the oligodendrocyte/type- 2 astrocyte progenitor ceil. Nature 333, 560-562. doi: 10.1038/333560a0

Noll, E., and Miller, R. H. (1993). Oligodendrocyte precursors originate at the ventral ventricular zone dorsal to the ventral midline region in the embryonic rat spinal cord. Development $118,563-573$.

Nortley, R., and Attwell, D. (2017). Control of brain energy supply by astrocytes. Curr. Opin. Neurobiol. 47, 80-85. doi: 10.1016/j.conb.2017.09.012

Ono, K., Bansal, R., Payne, J., Rutishauser, U., and Miller, R. H. (1995). Early development and dispersal of oligodendrocyte precursors in the embryonic chick spinal cord. Development 121, 1743-1754.

Oosterhof, N., Kuil, L. E., van der Linde, H. C., Burm, S. M., Berdowski, W., van Ijcken, W. F. J., et al. (2018). Colony-stimulating factor 1 receptor (csflr) regulates microglia density and distribution, but not microglia differentiation in vivo. Cell Rep. 24, 1203-1217. doi: 10.1016/j.celrep.2018.06.113

Orthmann-Murphy, J. L., Enriquez, A. D., Abrams, C. K., and Scherer, S. S. (2007a). Loss-of-function GJA12/Connexin 47 mutations cause pelizaeus-merzbacherlike disease. Mol. Cell. Neurosci. 34, 629-641. doi: 10.1016/j.mcn.2007. 01.010

Orthmann-Murphy, J. L., Freidin, M., Fischer, E., Scherer, S. S., and Abrams, C. K. (2007b). Two distinct heterotypic channels mediate gap junction coupling between astrocyte and oligodendrocyte connexins. J. Neurosci. 27, 1394913957. doi: 10.1523/JNEUROSCI.3395-07.2007

Ostrow, L. W., Suchyna, T. M., and Sachs, F. (2011). Stretch induced endothelin1 secretion by adult rat astrocytes involves calcium influx via stretch-activated ion channels (SACs). Biochem. Biophys. Res. Commun. 410, 81-86. doi: 10.1016/ j.bbrc.2011.05.109

Pan, S., Mayoral, S. R., Choi, H. S., Chan, J. R., and Kheirbek, M. A. (2020). Preservation of a remote fear memory requires new myelin formation. Nat. Neurosci. 23, 487-499. doi: 10.1038/s41593-019-0582-1

Park, J., Jung, E., Lee, S.-H., and Chung, W.-S. (2020). CDC50A dependent phosphatidylserine exposure induces inhibitory post-synapse elimination by microglia. bioRxiv 2020:060616. doi: 10.1101/2020.04.25.060616

Parkhurst, C. N., Yang, G., Ninan, I., Savas, J. N., Yates, J. R., Lafaille, J. J., et al. (2013). Microglia promote learning-dependent synapse formation through brain-derived neurotrophic factor. Cell 155, 1596-1609. doi: 10.1016/j.cell.2013. 11.030

Philippot, C., Griemsmann, S., Jabs, R., Seifert, G., Kettenmann, H., and Steinhäuser, C. (2021). Astrocytes and oligodendrocytes in the thalamus jointly maintain synaptic activity by supplying metabolites. Cell Rep. 34:108642. doi: 10.1016/j.celrep.2020.108642

Philips, T., Mironova, Y. A., Jouroukhin, Y., Chew, J., Vidensky, S., Farah, M. H., et al. (2021). MCT1 deletion in oligodendrocyte lineage cells causes late-onset hypomyelination and axonal degeneration. Cell Rep. 34:108610. doi: 10.1016/j. celrep.2020.108610

Pitt, J., Wilcox, K. C., Tortelli, V., Diniz, L. P., Oliveira, M. S., Dobbins, C., et al. (2017). Neuroprotective astrocyte-derived insulin/insulin-like growth factor 1 stimulates endocytic processing and extracellular release of neuron-bound $A \beta$ oligomers. Mol. Biol. Cell 28, 2623-2636. doi: 10.1091/mbc.e17-06-0416

Poliak, S., Salomon, D., Elhanany, H., Sabanay, H., Kiernan, B., Pevny, L., et al. (2003). Juxtaparanodal clustering of Shaker-like K channels in myelinated axons depends on Caspr2 and TAG-1. J. Cell Biol. 162, 1149-1160. doi: 10.1083/ jcb. 200305018

Poskanzer, K. E., and Yuste, R. (2011). Astrocytic regulation of cortical UP states. Proc. Natl. Acad. Sci. U S A. 108, 18453-18458. doi: 10.1073/pnas.1112378108

Prestoz, L., Chatzopoulou, E., Lemkine, G., Spassky, N., Lebras, B., Kagawa, T., et al. (2004). Control of axonophilic migration of oligodendrocyte precursor cells by Eph-ephrin interaction. Neuron Glia Biol. 1, 73-83. doi: 10.1017/ S1740925X04000109

Qian, X., Shen, Q., Goderie, S. K., He, W., Capela, A., Davis, A. A., et al. (2000). Timing of CNS cell generation: a programmed sequence of neuron and glial cell production from isolated murine cortical stem cells. Neuron 28, 69-80. doi: 10.1016/S0896-6273(00)00086-6 
Raff, M. (2007). Intracellular developmental timers. Cold Spring Harb Symp Quant Biol. 72, 431-435. doi: 10.1101/sqb.2007.72.007

Raff, M. C., Lillien, L. E., Richardson, W. D., Burne, J. F., and Noble, M. D. (1988). Platelet-derived growth factor from astrocytes drives the clock that times oligodendrocyte development in culture. Nature 333, 562-565. doi: 10. $1038 / 333562 \mathrm{a} 0$

Rasband, M. N., and Peles, E. (2016). The nodes of ranvier: molecular assembly and maintenance. Cold Spring Harb. Perspect. Biol. 8:a020495. doi: 10.1101/ cshperspect.a020495

Readhead, C., Popko, B., Takahashi, N., David Shine, H., Saavedra, R. A., Sidman, R. L., et al. (1987). Expression of a myelin basic protein gene in transgenic shiverer mice: correction of the dysmyelinating phenotype. Cell 48, 703-712. doi: 10.1016/0092-8674(87)90248-0

Richardson, W. D., Pringle, N., Mosley, M. J., Westermark, B., and Dubois-Dalcg, M. (1988). A role for platelet-derived growth factor in normal gliogenesis in the central nervous system. Cell 53, 309-319. doi: 10.1016/0092-8674(88)90392-3

Rojo, R., Raper, A., Ozdemir, D. D., Lefevre, L., Grabert, K., Wollscheid-Lengeling, E., et al. (2019). Deletion of a Csf1r enhancer selectively impacts CSF1R expression and development of tissue macrophage populations. Nat. Commun. 10:14. doi: 10.1038/s41467-019-11053-8

Saab, A. S., Tzvetavona, I. D., Trevisiol, A., Baltan, S., Dibaj, P., Kusch, K., et al. (2016). Oligodendroglial NMDA receptors regulate glucose import and axonal energy metabolism. Neuron 91, 119-132.

Saher, G., Brügger, B., Lappe-Siefke, C., Möbius, W., Tozawa, R. I., Wehr, M. C., et al. (2005). High cholesterol level is essential for myelin membrane growth Nat. Neurosci. 8, 468-475. doi: 10.1038/nn1426

Satoh, J., Kino, Y., Asahina, N., Takitani, M., Miyoshi, J., Ishida, T., et al. (2016). TMEM119 marks a subset of microglia in the human brain. Neuropathology 36 , 39-49. doi: 10.1111/neup. 12235

Scheller, M., Foerster, J., Heyworth, C. M., Waring, J. F., Löhler, J., Gilmore, G. L., et al. (1999). Altered development and cytokine responses of myeloid progenitors in the absence of transcription factor, interferon consensus sequence binding protein. Blood 94, 3764-3771. doi: 10.1182/blood.V94.11. 3764

Scholz, J., Klein, M. C., Behrens, T. E. J., and Johansen-Berg, H. (2009). Training induces changes in white-matter architecture. Nat. Neurosci. 12, 1370-1371. doi: $10.1038 / \mathrm{nn} .2412$

Scott-Hewitt, N., Perrucci, F., Morini, R., Erreni, M., Mahoney, M., Witkowska, A., et al. (2020). Local externalization of phosphatidylserine mediates developmental synaptic pruning by microglia. EMBO J. 39:e105380. doi: 10 . 15252/embj.2020105380

Serwanski, D. R., Jukkola, P., and Nishiyama, A. (2017). Heterogeneity of astrocyte and NG2 cell insertion at the node of ranvier. J. Comp. Neurol. 525, 535-552. doi: $10.1002 / \mathrm{cne} .24083$

Shiau, C. E., Kaufman, Z., Meireles, A. M., and Talbot, W. S. (2015). Differential requirement for irf8 in formation of embryonic and adult macrophages in zebrafish. PLoS One 10:e0117513. doi: 10.1371/journal.pone.01 17513

Shigemoto-Mogami, Y., Hoshikawa, K., Goldman, J. E., Sekino, Y., and Sato, K. (2014). Microglia enhance neurogenesis and oligodendrogenesis in the early postnatal subventricular zone. J. Neurosci. 34, 2231-2243. doi: 10.1523/ JNEUROSCI.1619-13.2014

Silva, M. E., Lange, S., Hinrichsen, B., Philp, A. R., Reyes, C. R., Halabi, D., et al. (2019). Pericytes favor oligodendrocyte fate choice in adult neural stem cells. Front. Cell. Neurosci. 13:85. doi: 10.3389/fncel.2019.00085

Smith, M. E., and Hoerner, M. T. (2000). Astrocytes modulate macrophage phagocytosis of myelin in vitro. J. Neuroimmunol. 102, 154-162. doi: 10.1016/ S0165-5728(99)00218-0

Sorensen, A., Moffat, K., Thomson, C., and Barnett, S. C. (2008). Astrocytes, but not olfactory ensheathing cells or Schwann cells, promote myelination of CNS axonsin vitro. Glia 56, 750-763. doi: 10.1002/glia.20650

Spitzer, S. O., Sitnikov, S., Kamen, Y., Evans, K. A., Kronenberg-Versteeg, D., Dietmann, S., et al. (2019). Oligodendrocyte progenitor cells become regionally diverse and heterogeneous with age. Neuron 101, 459-471. doi: 10.1016/j. neuron.2018.12.020

Stankoff, B., Aigrot, M. S., Noël, F., Wattilliaux, A., Zalc, B., and Lubetzki, C. (2002). Ciliary neurotrophic factor (CNTF) enhances myelin formation: a novel role for CNTF and CNTF-related molecules. J. Neurosci. 22, 9221-9227. doi: 10.1523/jneurosci.22-21-09221.2002

Steadman, P. E., Xia, F., Ahmed, M., Mocle, A. J., Penning, A. R. A., Geraghty, A. C., et al. (2020). Disruption of oligodendrogenesis impairs memory consolidation in adult mice. Neuron 105, 150-164. doi: 10.1016/j.neuron.2019.10.013

Stowell, R. D., Sipe, G. O., Dawes, R. P., Batchelor, H. N., Lordy, K. A., Whitelaw, B. S., et al. (2019). Noradrenergic signaling in the wakeful state inhibits microglial surveillance and synaptic plasticity in the mouse visual cortex. Nat. Neurosci. 22, 1782-1792. doi: 10.1038/s41593-019-0514-0

Su, Z., Yuan, Y., Chen, J., Zhu, Y., Qiu, Y., Zhu, F., et al. (2011). Reactive astrocytes inhibit the survival and differentiation of oligodendrocyte precursor cells by secreted TNF- $\alpha$. J. Neurotrauma 28, 1089-1100. doi: 10.1089/neu.2010.1597

Sutor, B., Schmolke, C., Teubner, B., Schirmer, C., and Willecke, K. (2000). Myelination defects and neuronal hyperexcitability in the neocortex of connexin 32-deficient mice. Cereb. Cortex 10, 684-697. doi: 10.1093/cercor/10. 7.684

Swire, M., Kotelevtsev, Y., Webb, D. J., Lyons, D. A., and Ffrench-Constant, C. (2019). Endothelin signalling mediates experience-dependent myelination in the CNS. Elife 8:e49493. doi: 10.7554/eLife.49493

Taylor, D. L., Pirianov, G., Holland, S., McGinnity, C. J., Norman, A. L., Reali, C., et al. (2010). Attenuation of proliferation in oligodendrocyte precursor cells by activated microglia. J. Neurosci. Res. 88, 1632-1644. doi: 10.1002/jnr.22335

Temple, S., and Raff, M. C. (1986). Clonal analysis of oligodendrocyte development in culture: Evidence for a developmental clock that counts cell divisions. Cell 44, 773-779. doi: 10.1016/0092-8674(86)90843-3

Thakurela, S., Garding, A., Jung, R. B., Müller, C., Goebbels, S., White, R., et al. (2016). The transcriptome of mouse central nervous system myelin. Sci. Rep. 6:25828. doi: 10.1038/srep25828

Thornton, M. A., and Hughes, E. G. (2020). Neuron-oligodendroglia interactions: activity-dependent regulation of cellular signaling. Neurosci. Lett. 727:134916. doi: 10.1016/j.neulet.2020.134916

Tomassy, G. S., Berger, D. R., Chen, H. H., Kasthuri, N., Hayworth, K. J., Vercelli, A., et al. (2014). Distinct profiles of myelin distribution along single axons of pyramidal neurons in the neocortex. Science 344, 319-324. doi: 10.1126/science. 1249766

Traka, M., Goutebroze, L., Denisenko, N., Bessa, M., Nifli, A., Havaki, S., et al. (2003). Association of TAG-1 with Caspr2 is essential for the molecular organization of juxtaparanodal regions of myelinated fibers. J. Cell Biol. 162, 1161-1172. doi: $10.1083 /$ jcb. 200305078

Trotter, J., DeJong, L. J., and Smith, M. E. (1986). Opsonization with antimyelin antibody increases the uptake and intracellular metabolism of myelin in inflammatory macrophages. J. Neurochem. 47, 779-789. doi: 10.1111/j.14714159.1986.tb00679.x

Tsai, H. H., Niu, J., Munji, R., Davalos, D., Chang, J., Zhang, H., et al. (2016). Oligodendrocyte precursors migrate along vasculature in the developing nervous system. Science 351, 379-384. doi: 10.1126/science.aad 3839

Utz, S. G., See, P., Becher, B., and Ginhoux, F. (2020). Early fate defines microglia and non-parenchymal brain macrophage development. Cell 181, 557-573. doi: 10.1016/j.cell.2020.03.021

van der Laan, L. J., Ruuls, S. R., Weber, K. S., Lodder, I. J., Dopp, E. A., and Dijkstra, C. D. (1996). Macrophage phagocytosis of myelin in vitro determined by flow cytometry: phagocytosis is mediated by CR3 and induces production of tumor necrosis factor-alpha and nitric oxide. Artic. J. Neuroimmunol. 70, 145-152. doi: 10.1016/0165-5728(96)00110-5

Wake, H., Ortiz, F. C., Woo, D. H., Lee, P. R., Angulo, M. C., Fields, R. D., et al. (2015). Nonsynaptic junctions on myelinating glia promote preferential myelination of electrically active axons. Nat. Commun. 6:7844. doi: 10.1038/ ncomms 8844

Wang, F., Ren, S. Y., Chen, J. F., Liu, K., Li, R. X., Li, Z. F., et al. (2020). Myelin degeneration and diminished myelin renewal contribute to age-related deficits in memory. Nat. Neurosci. 23, 481-486. doi: 10.1038/s41593-0200588-8

Wasseff, S. K., and Scherer, S. S. (2011). Cx32 and Cx47 mediate oligodendrocyte:astrocyte and oligodendrocyte:oligodendrocyte gap junction coupling. Neurobiol. Dis. 42, 506-513. doi: 10.1016/j.nbd.2011. 03.003 
Wasseff, S. K., and Scherer, S. S. (2015). Activated immune response in an inherited leukodystrophy disease caused by the loss of oligodendrocyte gap junctions. Neurobiol. Dis. 82, 86-98. doi: 10.1016/j.nbd.2015.05.018

Watkins, T. A., Emery, B., Mulinyawe, S., and Barres, B. A. (2008). Distinct stages of myelination regulated by $\gamma$-secretase and astrocytes in a rapidly myelinating CNS coculture system. Neuron 60, 555-569. doi: 10.1016/j.neuron.2008. 09.011

Werkman, I. L., Kövilein, J., Jonge, J. C., Baron, W., de Jonge, J. C., and Baron, W. (2020). Impairing committed cholesterol biosynthesis in white matter astrocytes, but not grey matter astrocytes, enhances in vitro myelination. J. Neurochem. 156, jnc15113. doi: 10.1111/jnc.15113

Wheeler, N. A., and Fuss, B. (2016). Extracellular cues influencing oligodendrocyte differentiation and (re)myelination. Exp. Neurol. 283, 512-530. doi: 10.1016/j. expneurol.2016.03.019

Wilson, C. H., and Hartline, D. K. (2011). Novel organization and development of copepod myelin. II. nonglial origin. J. Comp. Neurol. 519, 3281-3305. doi: 10.1002/cne.22699

Winkler, C. C., Yabut, O. R., Fregoso, S. P., Gomez, H. G., Dwyer, B. E., Pleasure, S. J., et al. (2018). The dorsal wave of neocortical oligodendrogenesis begins embryonically and requires multiple sources of sonic hedgehog. J. Neurosci. 38, 5237-5250. doi: 10.1523/JNEUROSCI.3392-17.2018

Wlodarczyk, A., Holtman, I. R., Krueger, M., Yogev, N., Bruttger, J., Khorooshi, R., et al. (2017). A novel microglial subset plays a key role in myelinogenesis in developing brain. EMBO J. 36, 3292-3308. doi: 10.15252/embj.201696056

Yang, S. M., Michel, K., Jokhi, V., Nedivi, E., and Arlotta, P. (2021). Neuron classspecific responses govern adaptive myelin remodeling in the neocortex. Science 370:eabd2109. doi: 10.1126/science.abd2109

Ye, P., Li, L., Richards, R. G., DiAugustine, R. P., and D’Ercole, A. J. (2002). Myelination is altered in insulin-like growth factor-I null mutant mice. J. Neurosci. 22, 6041-6051. doi: 10.1523/jneurosci.22-14-06041.2002

Yeh, H. J., He, Y. Y., Xu, J., Hsu, C. Y., and Deuel, T. F. (1998). Upregulation of pleiotrophin gene expression in developing microvasculature, macrophages, and astrocytes after acute ischemic brain injury. J. Neurosci. 18, 3699-3707. doi: 10.1523/jneurosci.18-10-03699.1998

Yergert, K. M., Doll, C. A., O’Rouke, R., Hines, J. H., and Appel, B. (2021). Identification of $3^{\prime}$ UTR motifs required for mRNA localization to myelin sheaths in vivo. PLoS Biol. 19:e3001053. doi: 10.1371/journal.pbio.3001053

Yeung, M. S. Y., Zdunek, S., Bergmann, O., Bernard, S., Salehpour, M., Alkass, K., et al. (2014). Dynamics of oligodendrocyte generation and myelination in the human brain. Cell 159, 766-774. doi: 10.1016/j.cell.2014.10.011

York, E. M., Bernier, L.-P., and MacVicar, B. A. (2018). Microglial modulation of neuronal activity in the healthy brain. Dev. Neurobiol. 78, 593-603. doi: 10.1002/dneu.22571

Yuen, T. J., Silbereis, J. C., Griveau, A., Chang, S. M., Daneman, R., Fancy, S. P. J., et al. (2014). Oligodendrocyte-encoded HIF function couples postnatal myelination and white matter angiogenesis. Cell 158, 383-396. doi: 10.1016/j. cell.2014.04.052

Zuchero, J. B., Fu, M. M., Sloan, S. A., Ibrahim, A., Olson, A., Zaremba, A., et al. (2015). CNS myelin wrapping is driven by actin disassembly. Dev. Cell 34, 152-167. doi: 10.1016/j.devcel.2015.06.011

Zuend, M., Saab, A. S., Wyss, M. T., Ferrari, K. D., Hösli, L., Looser, Z. J., et al. (2020). Arousal-induced cortical activity triggers lactate release from astrocytes. Nat. Metab. 2, 179-191. doi: 10.1038/s42255-020-0170-4

Conflict of Interest: The author declares that the research was conducted in the absence of any commercial or financial relationships that could be construed as a potential conflict of interest.

Copyright (c) 2021 Hughes. This is an open-access article distributed under the terms of the Creative Commons Attribution License (CC BY). The use, distribution or reproduction in other forums is permitted, provided the original author(s) and the copyright owner(s) are credited and that the original publication in this journal is cited, in accordance with accepted academic practice. No use, distribution or reproduction is permitted which does not comply with these terms. 